\title{
Understanding Host-Pathogen Interactions in Brassica napus in the Omics Era
}

\author{
Ting Xiang Neik ${ }^{1}$, Junrey Amas ${ }^{2}$, Martin Barbetti ${ }^{3}$, David Edwards ${ }^{2}$ \\ and Jacqueline Batley ${ }^{2, * \mathbb{D}}$ \\ 1 Sunway College Kuala Lumpur, Bandar Sunway 47500, Selangor, Malaysia; tingxiang@gmail.com \\ 2 School of Biological Sciences and Institute of Agriculture, The University of Western Australia, \\ Perth 6009, Australia; junrey.amas@research.uwa.edu.au (J.A.); dave.edwards@uwa.edu.au (D.E.) \\ 3 School of Agriculture and Environment and Institute of Agriculture, The University of Western Australia, \\ Perth 6009, Australia; martin.barbetti@uwa.edu.au \\ * Correspondence: jacqueline.batley@uwa.edu.au
}

Received: 16 September 2020; Accepted: 6 October 2020; Published: 10 October 2020

\begin{abstract}
Brassica napus (canola/oilseed rape/rapeseed) is an economically important crop, mostly found in temperate and sub-tropical regions, that is cultivated widely for its edible oil. Major diseases of Brassica crops such as Blackleg, Clubroot, Sclerotinia Stem Rot, Downy Mildew, Alternaria Leaf Spot and White Rust have caused significant yield and economic losses in rapeseed-producing countries worldwide, exacerbated by global climate change, and, if not remedied effectively, will threaten global food security. To gain further insights into the host-pathogen interactions in relation to Brassica diseases, it is critical that we review current knowledge in this area and discuss how omics technologies can offer promising results and help to push boundaries in our understanding of the resistance mechanisms. Omics technologies, such as genomics, proteomics, transcriptomics and metabolomics approaches, allow us to understand the host and pathogen, as well as the interaction between the two species at a deeper level. With these integrated data in multi-omics and systems biology, we are able to breed high-quality disease-resistant Brassica crops in a more holistic, targeted and accurate way.
\end{abstract}

Keywords: Brassica napus; host-pathogen interaction; pathosystems; omics; next-generation sequencing (NGS); pangenomics; secretomics; bioinformatics

\section{Introduction}

Plants interact very closely with microorganisms, such as fungi and bacteria, in the natural environment through a symbiotic relationship with endophytes, often having beneficial effects on the plant [1]. By contrast, a parasitic relationship with pathogenic microbes has harmful effects on the plant. In a parasitic relationship, the plant plays host while the fungal or bacterial pathogen feeds off the nutrients from the host at the host's expense. Depending on the mode of nutrition, plant pathogens are classified as (a) biotrophic, where the pathogen obtains nutrients from the living plant without causing the plant to die; (b) necrotrophic, where the pathogen kills off the plant and utilizes the nutrients that are released; or (c) hemibiotrophic, where the pathogen transitions from biotrophic to necrotrophic in different stages of invasion in the host [2].

Plants, in response, protect themselves from pathogen attack typically through two divisions of immunity. The first is the innate immune response, also known as PAMP (pathogen-associated molecular pattern)-triggered immunity (PTI). This provides defence against a broad range of pathogens involving cell surface plant pattern recognition receptors (PRRs) recognising extracellular PAMPs. The second is adaptive immunity, also referred to as effector-triggered immunity (ETI). This provides 
complete resistance to the host and is mediated by a specific interaction between the resistance $(R)$ gene in the host and the effector (Avirulence, Avr) gene in the pathogen [3,4]. The tight relationship between the host and the pathogen is a result of a long-term co-evolutionary process where the fungal pathogen and the host plant each strive to keep ahead by evolving ways to overcome resistance/pathogenicity [5], as described in the PTI/ETI zigzag model of the plant immune system [6]. Newer models, such as "effector-triggered defence" (ETD) [7], the "invasion model" [8], the "spatial immunity model" [9] and the "spatial invasion model" [10], have also been proposed. These accommodate the recognition of pathogens at the host immune receptors at a wider level, not restricted to the assignment of the PTI response to PRR proteins and the ETI response to $R$ genes, during defence signalling.

Brassica napus is an allopolyploid (AACC genome, $n=19$ ) belonging to the family Brassicaceae. The Brassicaceae constitute 325 genera and 3740 species [11,12], with the genus Brassica having 73 accepted species [13,14]. The six most important Brassica species are B. rapa (AA genome), B. nigra (BB genome), B. oleracea (CC genome), B. napus (AACC genome), B. juncea (AABB genome) and B. carinata (BBCC genome). These six species are cultivated as vegetables, oilseeds and condiments, and display a wide variety of morphotypes, including as leafy vegetables such as Chinese cabbage and pak choi in B. rapa, the enlarged inflorescences of cauliflower and broccoli in B. oleracea, and the condiment seeds of mustard plants in B. nigra and B. juncea $[15,16]$. B. napus is an oilseed crop that is traded globally and a major cash crop [14]. B. napus is widely grown in Europe, Canada, China and Australia [17] and ranks second after the soybean in terms of world oilseed production (75,001,457 tonnes vs. 348,712,311 tonnes) [18]. There is a pressing need for improving B. napus crop yield for high-quality and sustainable production to meet the growing demand of food consumption. This faces two challenges-first, the predicted increase in the human population to 9 billion by 2050, and second, the impact of unpredicted weather patterns worldwide due to global climate change $[19,20]$.

B. napus plays host to several fungal pathogens that cause major diseases leading to substantial loss in global production. These diseases include Blackleg (hemibiotrophic fungal pathogen Leptosphaeria maculans), Clubroot (obligate biotrophic protist/chytrid Plasmodiophora brassicae), Sclerotinia Stem Rot (necrotrophic and more recently proposed as a hemibiotrophic fungal pathogen Sclerotinia sclerotiorum) [21], Downy Mildew (obligate biotrophic oomycete Hyaloperonospora brassicae), Alternaria Leaf Spot (necrotrophic fungal pathogen, particularly A. brassicae but also A. alternata and a range of other Alternaria spp.), and White Rust (obligate biotrophic oomycete Albugo candida) [22,23]. These diseases have widely caused a yield loss of $24-50 \%$ and economic loss of up to USD 200 million in the $B$. napus industry, with the potential to wipe out the entire crop where not effectively controlled [24-29]. The most promising approach to controlling diseases of Brassica is through breeding disease-resistant varieties [30]. In this respect, the omics studies of B. napus pathosystems, integrating technologies from both the host and pathogen, are pertinent in breeding Brassica varieties that are better able to resist pathogen attack (Figure 1).

Here, we review the current status of the application of omics technologies to understand the molecular aspects of host-pathogen interactions in B. napus and other Brassica crops. We first discuss the application of omics technologies in the host, in relation to the identification of candidate QTL/R genes. We then discuss progress in pathogen research, focusing on the application of omics tools in the discovery of pathogenicity genes. Lastly, we review future perspectives and prospects for the utilisation of omics technologies in Brassica-pathogen research for breeding high-quality, more-resistant crop varieties. 


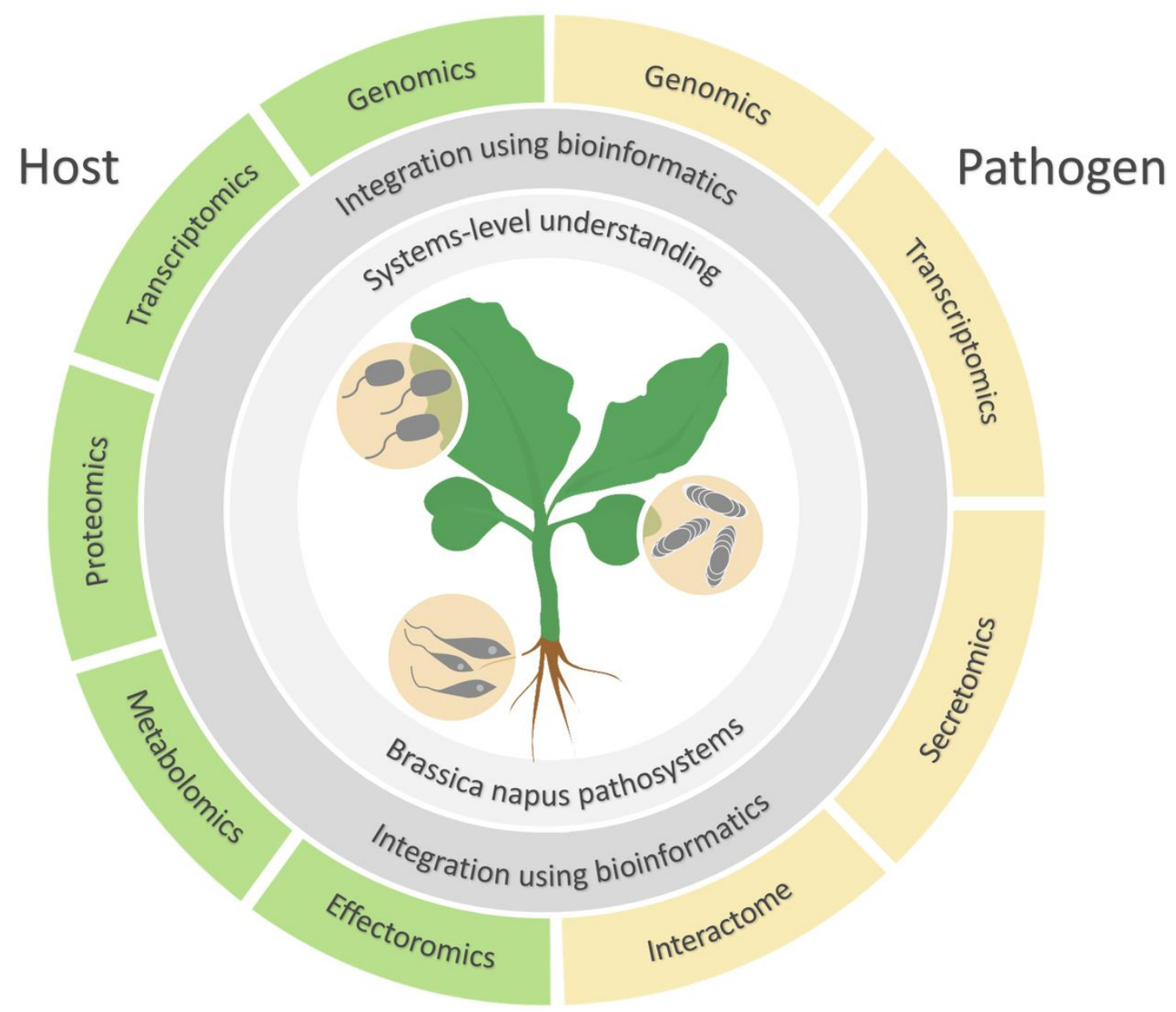

Figure 1. The integration of omics studies in B. napus pathosystems.

\section{Application of Omics Technologies in Brassica Host Plants}

\subsection{High-Quality Genome Assemblies}

With the introduction of next-generation sequencing (NGS) technology, five out of six Brassica crop genomes (B. rapa, B. oleracea, B. nigra, B. napus and B. juncea) have now been sequenced, with some species having more than one genome from different individuals [31-33]. The field of Brassica genomics has been "revolutionised" by the development of long-read sequencing technologies such as PacBio Single Molecule, Real-Time (PacBio) sequencing [34] and Oxford Nanopore Technologies (ONT) [35], along with high-throughput physical mapping technologies such as BioNano optical mapping [36] and Chromosome Conformation Capture (Hi-C) [37,38]. Valuable genomics resources for interrogating the molecular aspects of Brassica-pathogen interactions have been provided via high-quality genome assemblies of Brassica species using PacBio sequencing, for example, B. rapa cultivar "Chiifu-401-42" [39], B. oleracea cultivar "C-8" [40], B. napus German winter cultivar "Express 617" [33] and the recent improved B. napus "Darmor-bzh" [41], along with the highly contiguous B. nigra assembly, both achieved via ONT technology (Table 1). These high-quality Brassica assemblies resolve the "difficult" genomic regions commonly found in polyploid crops [42], particularly highly repetitive DNA sequences related to transposable elements (TEs), copy number variation (CNV), presence-absence variation (PAV) and homoeologous exchange, many of which are associated with disease resistance genes [43-45].

Although high-quality Brassica genome assemblies are currently available, such reference genomes and other Brassica genomes that were previously sequenced represent only a fraction of the Brassica morphotypes. For example, the reference B. rapa "Chiifu" is a heading type [39], while the reference "Z1" is a sarson type [46], the cauliflower B. oleracea "C- 8 " is an inflorescence type [40], and "TO1000" 
is a leafy type [47]. That genomes have not yet been assembled for other morphotypes in Brassica species, such as root or stem tubers in B. rapa (turnip), B. oleracea (kohlrabi) and B. napus (swede) [16], means that we may be missing out on much of the extensive genetic diversity present within the various Brassica species, but also that a wealth of novel alleles for disease resistance are potentially overlooked if we rely on a single reference genome. These issues have driven the development of pangenomes in plants.

\subsection{Pangenomics}

Pangenomics has been developed to overcome the limitations of relying on a single reference genome, and allows more comprehensive genomic variations to be identified from the gene pools represented by many lines within a species [48-50]. The recent pangenome of $B$. napus, which was built with eight $B$. napus lines encompassing three ecotypes using a de novo approach, showed the PAV regions were enriched with genes associated with a defence-related response [51]. Furthermore, in the B. oleracea and B. napus pangenomes, it was found that a large proportion of the disease resistance genes were dispensable, meaning that these genes are not present in all lines [44,52] (Table 1). These findings suggest that the $R$ genes in Brassica are highly variable, resulting from the strong selection pressure of arms-race evolution during host-pathogen interaction, superimposed by the frequent homoeologous exchanges between sub-genomes [44] during the domestication process within the Brassica lineage $[15,50]$. Hence, many candidate $R$ genes may have been missed from a single reference genome, thus hindering the speed of $R$ gene cloning in Brassica crops.

Pangenomics has identified a large $R$ gene repertoire, collectively known as resistance gene analogues (RGAs), in Brassica species. Examples of RGAs include nucleotide-binding site leucine-rich repeats (NLRs), mainly comprising the TIR-NBS-LRR (TNL) and CC-NBS-LRR (CNL) types, receptor-like protein kinases (RLKs), receptor-like proteins (RLPs) and wall-associated kinases [53,54]. Using pangenomics, 106 RGAs have been identified within the Blackleg QTL in the B. napus pangenome [45] while 59 RGAs were detected within the Sclerotinia, Fusarium wilt and Clubroot resistance QTLs in the B. oleracea pangenome [43]. These pangenomics studies revealed that different classes of RGAs (RLKs, TNLs and others) show different percentages of variability across the lines, which leads to the following question: is there any association between $R$ gene variability and resistance outcomes in Brassica crops for the major diseases? It was also found in the B. oleracea pangenome study that the wild relative $B$. macrocarpa harbours the most RGA candidates, suggesting that a large pool of genetic resources for $R$ genes can be found in wild Brassicas [43,52]. Recently, a super-pangenome was reported that includes the genomes of wild relatives and/or different species within a genus, which adds an additional level of depth for investigating genomic variations within a crop genus [55]. With a super-pangenome developed in Brassica crops, not only can we identify many more novel candidate disease resistance genes from the wild genotypes, but we can also develop molecular markers to screen for resistant varieties in the field, therefore not only improving the speed and accuracy of crop breeding but also broadening the Brassica gene pool by using novel alleles from wild germplasm. 
Table 1. Summary of the most recent Brassica reference genomes useful for omics studies in the Brassica pathosystems.

\begin{tabular}{|c|c|c|c|}
\hline Reference Genome & Approach & $\begin{array}{c}\text { Major Findings Relevant to } R \\
\text { Gene Study }\end{array}$ & Reference \\
\hline $\begin{array}{l}\text { Single genome } \\
\text { B. napus winter cultivar } \\
\text { "Express 617" }\end{array}$ & $\begin{array}{l}\text { PacBio, ONT, Illumina } \\
\text { HiSeq, Optical mapping }\end{array}$ & $\begin{array}{l}\text { Resolved break-point sequence at } \\
\text { homoeologous exchange regions }\end{array}$ & Lee, et al. [33] \\
\hline B. oleracea cultivar " $\mathrm{C}-8$ " & $\begin{array}{l}\text { PacBio, Illumina HiSeq, } \\
\text { transcriptomics }\end{array}$ & $\begin{array}{l}\text { Cauliflower is the most recent var. } \\
\text { to evolve within Brassica genus. } \\
\text { It contains more repetitive } \\
\text { sequences compared to other } \\
\text { B. oleracea species }\end{array}$ & Sun, et al. [40] \\
\hline $\begin{array}{l}\text { B. nigra accession } \\
\text { CGN7651 }\end{array}$ & ONT, Hi-C & $\begin{array}{c}\text { Hotspot of ALE-type retroelement } \\
\text { in the centromeric regions showed } \\
\text { that these retroelements play an } \\
\text { important role in the divergence of } \\
\text { B. nigra centromere }\end{array}$ & Perumal, et al. [56] \\
\hline $\begin{array}{l}\text { B. rapa cultivar } \\
\text { "Chiifu- } 401-42 \text { " }\end{array}$ & $\begin{array}{l}\text { PacBio, Optical mapping, } \\
\text { Hi-C }\end{array}$ & $\begin{array}{l}\text { V3.0, improved repeat reads, } \\
\text { defined locations of centromeres } \\
\text { and annotated more genes in these } \\
\text { difficult regions. Annotated higher } \\
\text { number of TEs }\end{array}$ & Zhang, et al. [39] \\
\hline \multicolumn{4}{|l|}{ Pangenome } \\
\hline $\begin{array}{l}\text { Eight } B . \text { napus accessions } \\
\text { of three ecotypes }\end{array}$ & $\begin{array}{l}\text { Alignment of de novo } \\
\text { assembled genomes against } \\
\text { "ZS11" }\end{array}$ & $\begin{array}{l}\text { PAV genes were highly represented } \\
\text { by defence response gene }\end{array}$ & Song, et al. [51] \\
\hline $\begin{array}{c}33 \text { non-synthetic and } 20 \\
\text { synthetic } B \text {. napus } \\
\text { accessions }\end{array}$ & $\begin{array}{c}\text { Iterative mapping and } \\
\text { assembly using improved } \\
\text { "Darmor-bzh"(v8.1) from } \\
\text { Bayer, Hurgobin, Golicz, } \\
\text { Chan, Yuan, Lee, Renton, } \\
\text { Meng, Li, Long, Zou, } \\
\text { Bancroft, Chalhoub, King, } \\
\text { Batley and Edwards [31] as } \\
\text { reference }\end{array}$ & $\begin{array}{l}\text { Homoeologous exchange-related } \\
\text { PAV genes highly represented by } \\
\text { defence, stress and auxin pathways }\end{array}$ & Hurgobin, et al. [44] \\
\hline $\begin{array}{l}\text { Nine } \text { B. oleracea } \\
\text { subspecies and wild type } \\
\text { comprising cabbage, } \\
\text { kale, Brussels sprouts, } \\
\text { kohlrabi, cauliflower, } \\
\text { broccoli and } \\
\text { B. macrocarpa }\end{array}$ & $\begin{array}{l}\text { Iterative mapping and } \\
\text { assembly using Chinese kale } \\
\text { rapid cycling line (TO1000) } \\
\text { as reference }\end{array}$ & $\begin{array}{c}18.7 \% \text { of genes showed PAV with } \\
\text { annotation of disease resistance } \\
\text { genes }\end{array}$ & Golicz, et al. [52] \\
\hline $\begin{array}{l}\text { Two B. rapa subspecies: } \\
\text { turnip and rapid cycling }\end{array}$ & $\begin{array}{l}\text { Alignment of de novo } \\
\text { assembled genomes against } \\
\text { "Chiifu" reference }\end{array}$ & $\begin{array}{l}\text { Peroxidase genes that are involved } \\
\text { in phenylpropanoid biosynthesis } \\
\text { response pathway during biotic } \\
\text { stress are unique in turnip, with } \\
\text { evidence of copy number variation }\end{array}$ & Lin, et al. [57] \\
\hline
\end{tabular}

\subsection{Identification of Candidate QTLs/Genes Using NGS-Based SNP Methods}

In the past two decades, many genetic linkage maps of Brassica crops have been generated, using bi-parental crossing, selfing and backcrosses, with molecular markers such as Restriction Fragment Length Polymorphisms (RFLPs), Amplified Fragment Length Polymorphisms (AFLPs) and Randomly Amplified Polymorphic DNA (RAPDs) reviewed by Delourme, et al. [58]. These molecular markers are often limited by low reproducibility and laborious techniques, thus limiting the quality of marker information in Brassica crops [59]. The genomics era, driven by the innovation of high-throughput next-generation sequencing (NGS) technologies, has significantly increased the efficiency of the identification of QTL/candidate genes for disease resistance in Brassica crops through the development of genome-wide DNA-based molecular markers. This has brought great improvement in the resolution of genetic maps [60].

Among the DNA-based molecular markers, single nucleotide polymorphism (SNP) markers are most widely used for determining genotypic variation in a given species because they are uniformly distributed and highly abundant in the genome and are amenable in multiple genotyping platforms [61,62]. With NGS, high-throughput genome-wide SNP marker development can be achieved 
rapidly and accurately in Brassica species through systems such as whole-genome resequencing (WGRS), genotyping-by-sequencing (GBS), and the Brassica 60K Illumina Infinium ${ }^{\mathrm{TM}}$ 60K SNP array [63].

WGRS is an omics strategy for obtaining high-quality, high-density SNP markers at a whole-genome level by mapping sequence reads to the Brassica reference genome assemblies [64]. In GBS, restriction enzymes are used to digest the genomic DNA and barcodes are used to ligate the fragmented DNA molecules before whole-genome sequencing is performed for SNP discovery [65]. In this way, GBS is less complicated compared to WGRS because the sequencing reads cover only part of the genome instead of the whole genome, thus offering a cost-efficient approach to identifying SNPs yet achieving equally high-quality SNPs with wide applications in crop improvement studies $[63,66]$. An extension of GBS called tGBS $^{\circledR}$ using oligonucleotides instead of adaptors has since been developed [67]. The Brassica 60K SNP array offers a whole-genome SNP genotyping approach that is highly reproducible for genotyping hundreds of DNA samples in $48 \mathrm{~h}$, making it an attractive option for the routine screening of Brassica germplasm [68-70]. A Brassica 60K SNP array data repository called CropSNPdb has been developed to enable users to access SNP information, currently containing genotypic information of 526 Brassica lines [71], permitting the easy retrieval of whole-genome SNP data for a wide range of downstream data analyses.

These NGS-based SNP genotyping approaches have been applied widely for the QTL mapping of disease resistance traits and identification of candidate genes through genome-wide association studies (GWAS) in Brassica crops (Table 2). Highlights include the discovery of novel disease resistance QTLs/genes at an unprecedented speed, for example, in Blackleg [72,73], Sclerotinia [74-76] and Clubroot [77-79]. The other benefit of the application of NGS-based SNP genotyping is the successful breeding of $B$. napus varieties containing multiple improved traits. For example, breeding was achieved through the introgression of several major QTLs for Sclerotinia quantitative resistance from B. oleracea into B. napus with good seed yield and quality [80]. In addition, bioinformatics pipelines are continuously being improved for whole-genome SNP data analysis. One example is Single Nucleotide Absence Polymorphism (SNaP) analysis, which successfully recovered numerous QTLs for Sclerotinia and Blackleg resistance in B. napus that were lost from the normal filtering of SNP data obtained from the Brassica 60K SNP array, with 3.2- and 2.2-fold increases in significant marker-trait associations for Sclerotinia and Blackleg resistance, respectively [81].

Table 2. Summary of application of next-generation sequencing (NGS)-based SNP genotyping approaches in resistance studies of Brassica diseases.

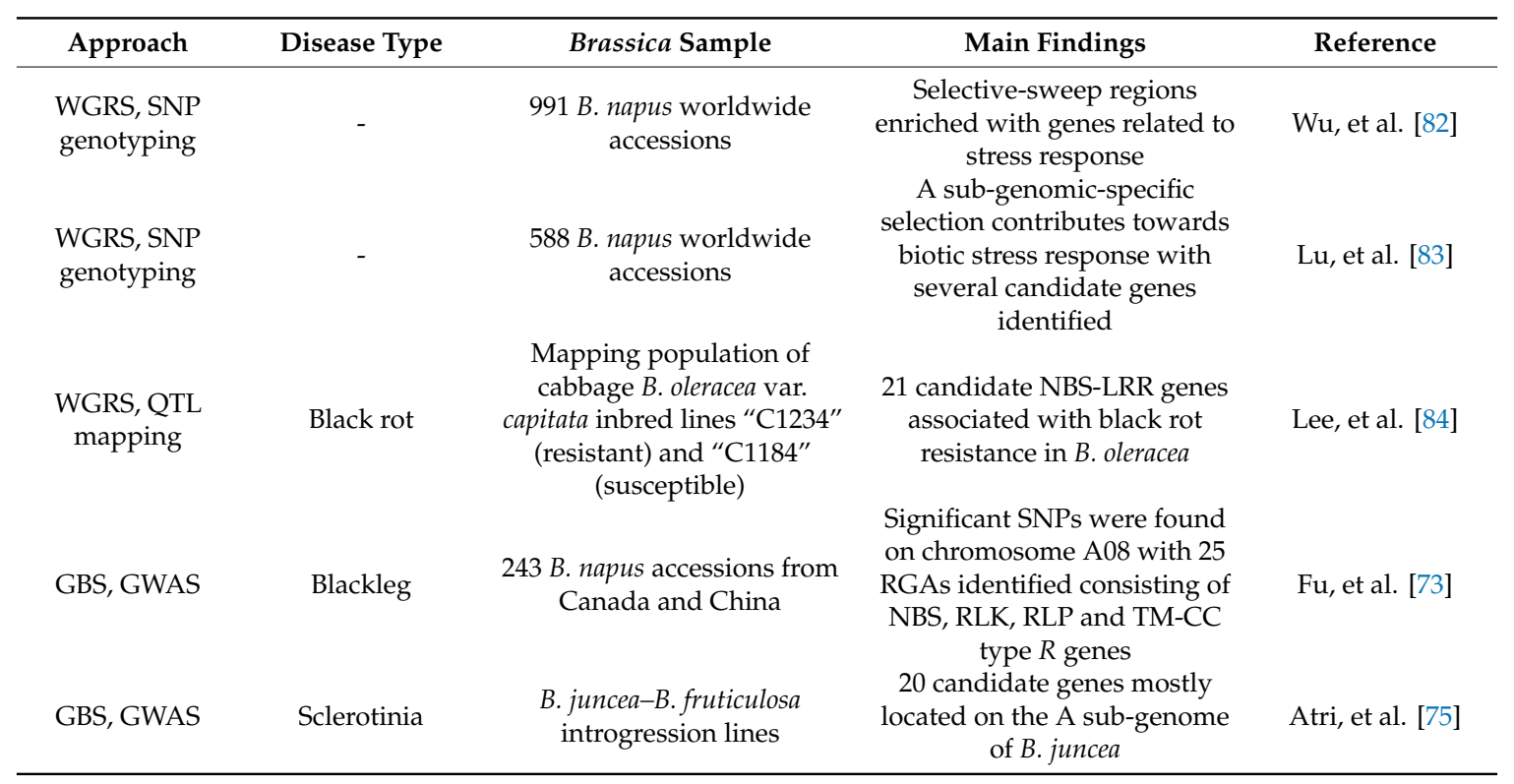


Table 2. Cont.

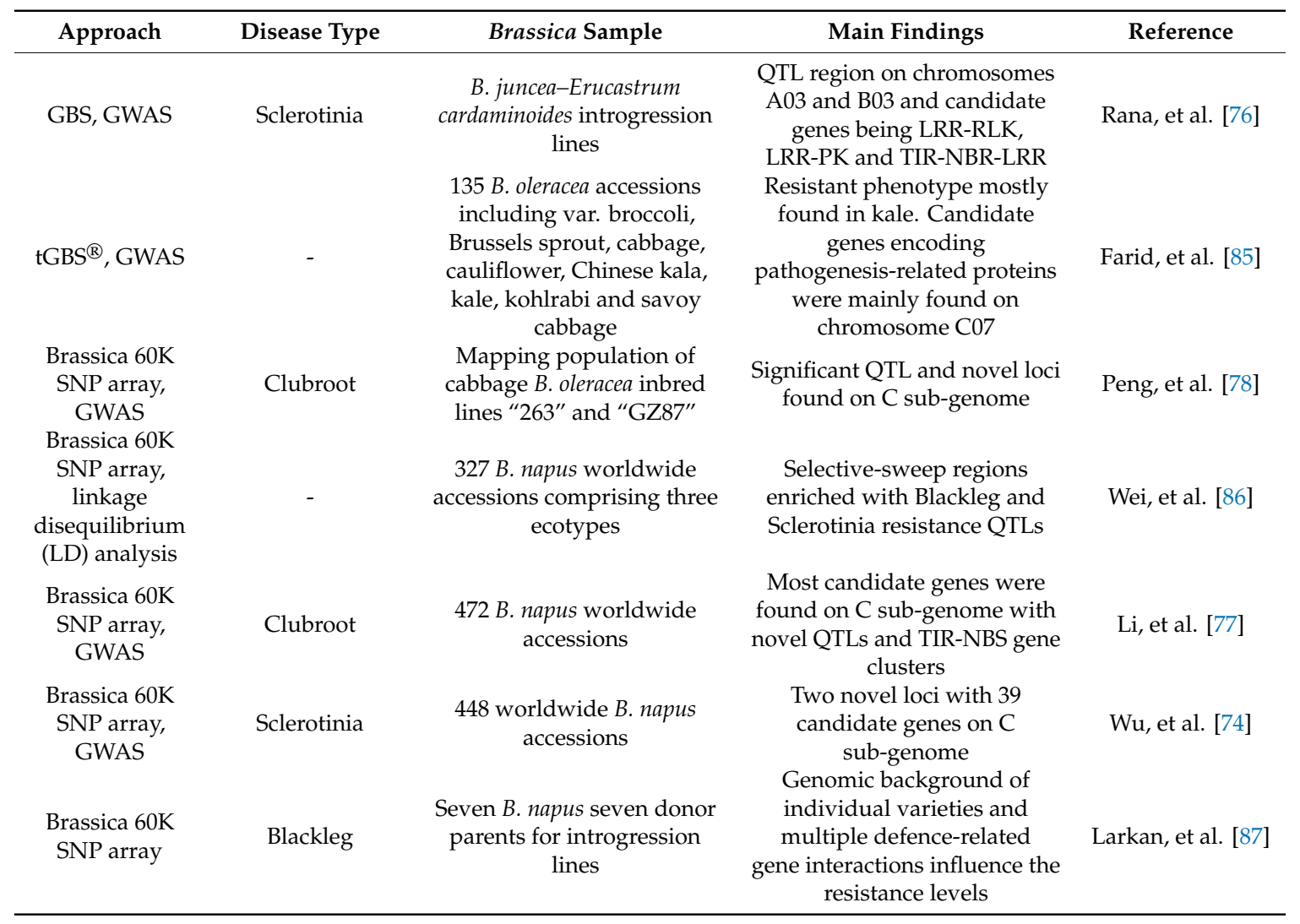

\subsection{Identification of Candidate R Gene Using In Silico Methods}

The large volume of Brassica genomics resources in public databases supports the analysis and interpretation of many complex mechanisms related to Brassica-pathogen interaction. Examples include the in silico identification of the Blackleg resistance gene, LepR4, in the C genome of Korean cabbage (B. oleracea var. capitata) [88] and the in silico exploration of 641 NBS-LRR-type disease resistance genes in $B$. napus, together highlighting the genomic distribution and structural variation of these genes in B. napus [89]. Other examples include the in silico evolutionary study of NBS genes in B. napus, where comparative genomic analysis highlighted the NBS gene's distribution from its progenitors B. rapa and B. oleracea in relation to the three main Brassica diseases-Blackleg, Clubroot and Sclerotinia [90]. Coupled with modern bioinformatics tools and the integration of multi-omics data sets, in silico methods are powerful tools that rapidly provide accurate and detailed models to answer various research questions ranging from candidate gene identification to evolutionary pathways of resistance mechanisms in both the Brassica host and the fungal pathogens [91]. This is a time-, cost- and manpower-effective means of conducting higher-quality Brassica crop improvement research investigations.

In addition, database searches for protein motifs associated with disease resistance genes have enabled researchers to identify classes of $R$ genes in B. napus that are associated with Blackleg, Sclerotinia and Clubroot resistance [92]. Stotz, et al. [92] suggest most Clubroot resistance genes are NLR type; Blackleg resistance genes are RLP type, while for Sclerotinia, neither NLR nor RLP were involved. Focusing on the NLR genes, comparative genomics and transcriptomics analyses supplemented with a database query on $B$. napus and its progenitors, $B$. rapa and B. oleracea, revealed many more NBS (also known as NLR) genes in the $C$ sub-genome of $B$. napus. A number of these genes underly the QTL regions for resistance against Blackleg, Sclerotinia and Clubroot, supporting the concept that the diversification of the $R$ genes likely happened after interspecific hybridisation between $B$. rapa and B. oleracea [90]. 


\subsection{NGS-Based Bulked Segregant Analysis (BSA)}

NGS-based BSA is one of the more recent applications of omics in studying Brassica-pathogen interactions. This technique involves bulks/pools of DNA samples with representations of individuals with segregating phenotypes, where the pools are genotyped using NGS, either RNA sequencing (BSR-Seq) or whole-genome resequencing, followed by the detection of QTLs through SNP calling between the bulks (QTL-Seq) [93,94]. The traditional BSA technique allows the screening of many loci. An example is screening for Downy Mildew resistance in lettuce [95], but it is restricted to the detection of random sequence variation (e.g., RFLPs) and requires intense PCR screening efforts to confirm the molecular markers that are linked with the selected genomic intervals. With the NGS screening of BSA populations, the detection of sequence polymorphisms between the bulks is rapid and effective, as novel variation, such as PAVs or even novel QTLs/genes, can potentially be detected [96].

Using BSR-Seq, an $R$ gene for resistance against Blackleg, Rlm1, was fine mapped in the B. napus cultivar "Quinta", and a candidate gene was identified, BnA07G27460D, that encodes a serine/threonine protein kinase. This gene is homologous to the protein kinase STN7 in B. rapa, B. oleracea and $A$. thaliana, which is involved in systemic plant immune responses by regulating reactive oxygen species (ROS)-induced cell signalling at the thylakoid membrane [97]. BSR-Seq has also been applied in characterising Clubroot resistance in some Brassica speciesl; for example, in B. oleracea, the first Clubroot major $R$ gene ( $R c r 7)$ in the B. oleracea cultivar "Tekila" was identified; Bo7g108760 was the candidate TNL gene [98]. In Chinese cabbage B. rapa var. pekinensis, the candidate gene Rcr2, which encodes a TIR-NBS-LRR, responsible for Clubroot resistance, has been identified on chromosome A03 [99]. In B. nigra, a novel Clubroot $R$ gene, $R c r 6$, was detected (BniBo15819, encoding a TNL gene), which is homologous to chromosome A08 of $B$. rapa and which provides a good source for gene introgression into B. napus [100]. Using QTL-Seq, two novel QTL regions associated with Clubroot resistance on chromosomes A07 and A08 were detected in pak choi B. campestris var. chinensis [96]. Lastly, a single novel candidate $R$ gene, also involved in Clubroot resistance, $C R d$, was identified on chromosome A03 of B. rapa [101].

\subsection{Resistance Gene Enrichment and Sequencing (RenSeq)}

RenSeq is a targeted resequencing method for identifying NLRs [102]. RenSeq in combination with PacBio sequencing was applied in $A$. thaliana to study the $R$ gene sequence variants of the White Rust Resistance (WRR) gene against Albugo candida [103]. This combinatorial approach was extended to 64 accessions of $A$. thaliana to study the evolution and variability of NLR genes in the model plant Arabidopsis, resulting in the construction of a species-wide pan-NLR-ome [104]. Similar to the concept of pangenomics, the pan-NLR-ome is the collection of all the NLR genes and alleles contained within a species, distinguishing between the core and non-core NLRs in terms of the structural variations and diversity. New domain structures of NLRs were identified from the pan-NLR-ome study in A. thaliana [104]. This implies that novel $R$ genes can be obtained from the diverse gene pool of NLRs within members of the Brassicaceae family, including Brassica crops. The discovery of a repertoire of NLRs is particularly important when pathogen-specific recognition can not only happen in the host species but also in the non-host species. For example, the non-host $A$. thaliana displayed ETI-mediated defence against $A$. candida isolates derived from $B$. juncea, B. rapa and B. oleracea [103], implying that $R$ genes play a conserved role across members within the same family. This implies that screening for novel $R$ genes for Brassica crop improvement should also be applied across non-host species. Pan-NLR-ome type studies contribute significantly towards the discovery of $R$ gene diversity in crops.

\subsection{Effectoromics}

Effectoromics, or effector-based screening, is an omics approach to detecting $R$ genes in crop plants, although $R$ gene products may not necessarily interact with effectors directly. In this method, the target effector, as forecast from prediction tools, is transformed using Agrobacterium and infiltrated 
onto the host plants. The host genotypes that give a positive response to the target effector are then subjected to resistance gene mapping using molecular markers [105]. Effectoromics allows screening for potential recognition targets in a particular crop species, for example, immune receptors, and can be applied to screen different crop species with a selection of potential candidates that can be used in inter-crop species [106]. This method was used for the identification of $R$ genes in the wild potato species S. pinnatisectum against the oomycete Phytophthora infestans $[107,108]$ and could be applied to Brassica pathosystems for the identification of $R$ genes.

\subsection{Transcriptomics}

Plant-pathogen interactions are complex, involving a breadth of interconnected molecular mechanisms [109]. Critical for understanding these mechanisms is deciphering which genes are activated in both the host and the pathogen during infection and how these genes affect the expression of others in the pathways. Transcriptome analysis has allowed the monitoring of the molecular cues involved in these interactions.

Gene expression analysis has already significantly evolved since early techniques were described and developed [110]. Recent approaches, including RNA sequencing or RNA-seq, overcome the limitations of previous techniques and are considered superior to predecessors in that they can interrogate the whole genome transcriptome of any organism with or without reference genomes and facilitate the discovery of unique genes [111]. They are highly sensitive in detecting lowly-expressed genes and have been shown to be highly reproducible. These features make RNA-seq the method of choice in most transcriptome studies, including the analysis of host-pathogen interactions. An advance in this approach, called dual-RNA seq, enables the simultaneous study of gene expression in both the host and pathogen [112,113], enabling a real-time and comprehensive analysis of the mechanisms involved in both pathogenesis and the host resistance response.

Furthermore, integrative approaches such as associative transcriptomics (AT) [114] and bulked RNA sequencing (BSR-Seq) [97] have allowed the incorporation of transcriptome data with genome-wide marker information to increase the power of detection for genomic loci controlling resistance or susceptibility in the host and virulence in the pathogen. These approaches have facilitated a fast-tracked identification of candidate genes underlying these loci and greatly facilitated the dissection of gene expression patterns during pathogen attack in important Brassica crops. AT is an RNA-based approach that integrates transcriptome data in GWAS to identify molecular markers associated with a particular trait of interest at marker loci where the levels of gene sequence and gene expression are variable [114]. AT is particularly useful for dissecting trait variation in polyploid species characterized as containing highly duplicated genes displaying variable expression patterns [115].

In $B$. napus resistance against Blackleg, three of the known $R$ genes have been cloned and were found to encode Leucine-Rich Repeats-Receptor Like Proteins (LRR-RLPs; Rlm2 and LepR3) and a wall-associated kinase-like (WAKL) protein $(R \operatorname{lm} 9)$ [116,117]. The cloning of these genes provided the starting material for using RNA-seq to interrogate the detailed machinery involved in the resistance. The global transcriptome analysis of Zhou, et al. [118] found that both LepR3 and Rlm2 evoked a basal defence response in both compatible and incompatible interactions upon inoculation with L. maculans isolates. This suggests that LepR3 and $R \operatorname{lm} 2$ may also monitor other molecular patterns produced by L. maculans to mount a resistance response in the host plant.

The $R \operatorname{lm} 9$ WAKL protein is a type of receptor-like kinase (RLK) localized in the cell wall, which functions to sense environmental and cellular signals [119]. Rlm9 is only the second WAKL $R$-gene identified to date; hence, the mechanisms underlying its resistance are yet to be studied in detail. Initially, Larkan, et al. [117] found Rlm9 did not seem to have a direct interaction with its counterpart Avr gene (AvrLm5-9), and it is likely that a mediator molecule, such as damage-associated molecular patterns (DAMPs), is needed to effect resistance. This is supported by the findings of Brutus, et al. [120], which showed that WAKLs can detect DAMPs following pathogen attack. However, this latter mechanism needs to be verified in further studies. Genome-wide transcriptome analysis 
for this interaction should help uncover how $R \operatorname{lm} 9$ orchestrates race-specific resistance responses against the Blackleg pathogen. Furthermore, as $R \operatorname{lm} 9$ forms part of the tightly linked $R$-gene cluster (Rlm3/4/7/9) on chromosome A07 of B. napus, the cloning of this gene may enable an understanding of the molecular mechanisms of the other genes on this cluster.

The introgression of the major genes Rlm2, Rlm3, LepR1 and LepR2 in cultivar "Topas" and LepR1 and LepR2 in "Westar" allowed the comparison of the effect of genetic background and $R$ gene content in host defence expression through genome-wide transcriptome profiling by Haddadi, et al. [121]. All the introgression lines (ILs) showed an upregulation of genes previously implicated in host defence, including hormone signalling, cell wall thickening, chitin production, and glucosinolate production. Interestingly, these genes have higher levels of expression in LepR1 and Rlm2 compared with LepR2 and $R \operatorname{lm} 3$ lines during the first three days of infection. Furthermore, a general trend of delayed defence responses in "Westar" compared with "Topas" ILs was observed, regardless of their $R$ gene content. This suggests that the genetic background has important effects on resistance. Additionally, there was enhanced expression of the RLK Brassica napus (Bn) SOBIR1 (Suppressor of BIR1-1) and salicylic acid-related defence in both LepR1 and Rlm2 lines, consistent with previous investigations [116,118,122]. Transcriptomic studies also showed the involvement of host receptor genes, for example, RLPs, RLKs, TIR-NBS and WAKLs, in PTI or effector-triggered defence (ETD) in the B. napus-L. maculans interaction [123]. All these studies suggest that Avr genes in L. maculans likely play a role in manipulating host resistance in the apoplast environment. The AvrLm1 protein reportedly interacts with the mitogen-activated protein kinase (MAPK) 9 in B. napus (BnMPK9) [124]. Furthermore, MAPK9 is implicated as a positive regulator of ROS-mediated abscisic acid (ABA) signalling in the guard cells of the plant, fostering stomatal closure [125,126]. Larkan, Ma and Borhan [116] previously reported the association of $B n-S O B I R$ with $R l m 2$, and it was assumed that the Rlm2 and Bn-SOBIR interaction results in downstream signalling to effect race-specific resistance against the AvrLm2 L. maculans pathotype. Given this information, it is likely that LepR1 conveys resistance through the same mechanism. Conversely, the expression of Bn-SOBIR was low in Rlm3 introgression lines, which means that $R \operatorname{lm} 3$ not only functions independently of the SOBIR1 interaction but represents another resistance mechanism different from that of other cloned genes. The cloning and transcriptomic analysis of this gene will shed light on the molecular mechanisms governing the operation of this resistance [121].

In the B. napus-Clubroot pathosystem, several $R$ genes acting against $P$. brassicae have been mapped, but only two have been cloned: $C R a$ [127] and $C r r 1 a$ [128], which encode TIR-NBS-LRRs. Plant hormones such as ethylene (ET), jasmonic acid (JA), salicylic acid (SA), abscisic acid (ABA), auxin and cytokinin were implicated in the pyramided lines of B. napus containing two Clubroot resistance genes, $P b B a 8.1$ and $C R b$, with the candidate genes involved in the hormone signalling pathway identified through comparative RNA-seq [129]. The transcriptome analysis in $C R b$-containing $B$. rapa lines, at the early stages of $P$. brassicae infection, confirmed the involvement of pathways typical for ETI-mediated resistance and biotrophic infection [130]. These include the activation of NLR and pathogenesis-related (PR) genes, along with the upregulation of genes for MAPK, WRKY transcription factors, calcium-binding proteins, chitinases, and SA pathway genes [131-133]. However, the transcriptome analysis of Chu, et al. [134] highlighted the induction of JA and ET pathways, implicated in the necrotrophic stage of infection, as important mechanisms of Rcr1-mediated resistance in B. rapa, thus highlighting a complex molecular mechanism for P. brassicae resistance in Brassica crops. The cloning of the Rcr1 gene will help to elucidate these hormones' induction dynamics. However, whilst Crr1 $a$ and $C R a$ have been cloned, the transcriptional control of their resistance has not been widely researched. Genome-wide transcriptome studies should help to elucidate the resistance mechanisms involved in these two key clubroot $R$ genes. To study the genetic effects of the multiple $R$ genes in pyramided lines and confirm the role of these introgressed genes in host resistance responses, comparative RNA sequencing could be performed. For example, when two Clubroot-resistant genes, $P b B a 8.1$ and $C R b$, were introgressed into a B. napus-pyramided line, through comparative RNA sequencing, it was found not only that the pyramided lines displayed a strong multi-gene resistance 
network during pathogen infection, but also that SA- and ROS-mediated resistance responses played a dominant role in the pyramided lines [129], supported by Galindo-González, et al. [135]'s study, highlighting the importance of SA-mediated resistance in the B. napus-P. brassicae pathosystem.

In a study of Sclerotinia resistance in B. napus, Qasim, et al. [136] detected at least 36 candidate genes representing diverse molecular functions in the resistance response, including TIR-NBS-LRR genes, hormone synthesis, the production of secondary metabolites, and the regulation of transcription factors and several metabolic pathways. One metabolic gene involved in the regulation of the phenylpropanoid pathway that plays a key role in lignin biosynthesis was highly transcribed across time points, and one TIR-NBS-LRR gene, in one of the QTL regions, a widely known $R$ gene that is associated with a qualitative response, was highly transcribed [136]. As Sclerotinia resistance has been known to be quantitatively controlled, the diversity of $R$-gene host-mediated resistance mechanisms shown in the study mirrors the complexity of quantitative resistance. Some of the described mechanisms are atypical of PTI- and ETI-mediated host defences, supporting an ongoing discussion challenging the applicability of the conventional two-tier model of plant immunity in explaining quantitative resistance variation. This enigma may be due to the differences in the hosts and the pathogens, as well as the approaches employed for studying genome-wide gene expression. Nevertheless, the increasing availability of transcriptome data generated through various high-throughput platforms results in a better comprehension of the mechanisms underpinning quantitative resistance. Global transcription sequencing also revealed that JA and ET signalling were associated with a resistance response against S. sclerotiorum in B. napus $[137,138]$; a further transcriptome study in the same pathosystem demonstrated the downregulation of B. napus NPR1-like gene, BnaNPR1, which plays a role in SA and JA signalling, indicating that $S$. sclerotiorum suppresses the expression of BnaNPR1 during systemic acquired resistance (SAR) for successful invasion into the host cell [139]. It is also noteworthy that NPR1 genes were activated by NBS-LRR genes, as reported in a gene pyramiding study in B. napus using two NBS-LRR genes, BvHs1 ${ }^{\text {pro-1 }}$ and BvcZR3, obtained from nematode (Heterodera schachtii)-resistant sugar beet [140]. The gene interaction network of NPR1 and NBS-LRR should be studied further in relation to other defence-related genes.

Comparative transcriptomic analysis of the B. napus-S. sclerotiorum pathosystem showed that indolic glucosinolate biosynthesis plays an important role [137], similar to that found from an overexpression experiment with three glucosinolate genes in B. napus, one of which, BnUGT74B1, encoding cytochrome P450, enhanced resistance to $S$. sclerotiorum [141]. Transcriptomic analysis in the B. oleracea-S. sclerotiorum interaction revealed a total of $45 \mathrm{~B}$. oleracea genes involved in $\mathrm{Ca}^{2+}$ signalling were upregulated, which is important in ROS generation [142], and this is consistent with the findings that the resistance mechanism in B. oleracea showed ROS generation and increased $\mathrm{Ca}^{2+}$ signalling contributing towards resistance outcomes in B. oleracea [143].

A transcriptome study of Downy Mildew (H. brassicae)-infected Chinese cabbage lines demonstrated the involvement of protein processing in endoplasmic reticulum and circadian rhythm pathways in resistance mechanisms [144]. In addition, the authors found the downregulation of photosynthetic genes during H. brassicae infection, which is consistent with Xiao, et al. [145], who reported a downregulation of energy metabolism genes, particularly those involved in the photosynthetic carbon cycle (PCC). This indicates that the resistance to H. brassicae in Brassica crops may be driven by efficient energy metabolism during pathogen invasion.

In an RNA-seq study of B. oleracea-Fusarium oxysporum f. sp. Conglutinans interactions, $\mathrm{Ca}^{2+}$-binding ATPase and aquaporin tonoplast intrinsic protein (TIP), which are involved in $\mathrm{Ca}^{2+}$ signalling, were highly expressed in the resistant genotype at $4 \mathrm{~h}$ after infection [146]. Similarly, the experiment of Tortosa, et al. [147], which examined the transcriptome dynamics in B. oleracea in response to the black rot pathogen (X. campestris), highlighted the role of $\mathrm{Ca}^{2+}$ signalling proteins as secondary messengers for several downstream signalling processes, including the activation of several transcription factors responsible for the initiation of SA-mediated host defence. The deep RNA-seq of Liu, et al. [148] found an upregulation of several plant pathogen receptor genes such as 
chitin elicitor receptor kinase 1, chitin receptor, LRR-RLPK and WAKL, which are important in the PTI defence response. This led them to conclude that PTI is the primary mechanism for soft rot resistance in Chinese cabbage (B. rapa var. pekinensis), initiating several downstream signalling pathways for hormone regulation and the production of secondary metabolites and cell wall reinforcement.

\subsection{Proteomics}

The use of 2D gel electrophoresis (2-DGE) and matrix-assisted laser desorption/ionisation time-of-flight mass spectrometry (MALDI-TOF/TOF MS) technology to study the proteomics of plant-pathogen interactions was first reported more than a decade ago [149]. Comparative proteomic analysis of responses to L. maculans, between compatible and incompatible interactions in B. napus cv. "Surpass 400" with either the virulent isolate UWA 192 or avirulent isolate UWAP11, showed the upregulation of enzymes involved in RuBisCO for $\mathrm{CO}_{2}$ fixation, $\mathrm{H}_{2} \mathrm{O}_{2}$ scavenging and redox metabolism [150]. In L. maculans-tolerant B. carinata, most of the proteins displayed antioxidant activities [151]. Similarly, in the B. carinata-L. maculans interaction, it was found from 2-DGE analysis that proteins related to ROS generation and photosynthetic enzymes were elevated in the resistant genotype $48 \mathrm{~h}$ after pathogen infection [152]. A proteomics study in the B. rapa-P. brassicae pathosystem showed Rcr1 was associated with the ubiquitin-related proteasome system in plant defence reactions, along with the activation of the calcium-independent MAPK signalling pathway, regulation of ROS production via the activity of protein disulfide isomerases and upregulation of lignin biosynthesis [153].

A high-throughput proteomic study using 2-DGE and MALDI-TOF/TOF MS analyses was performed in the B. oleracea-P. brassicae pathosystem to study protein expression during the early stages of host infection, with the highly expressed protein thioredoxin (TRX) enzyme identified, associated with oxidative stress and the pathogen defence response [154]. More than 487 out of 5003 proteins $(13.4 \%)$ that were identified in P. brassicae-infected Chinese cabbage (B. rapa var. pekinensis) using isobaric tags for relative and absolute quantitation (iTRAQ)-based proteomic analysis were differentially up- or downregulated, and the proteins that contributed to the defence response included those involved in tryptophan and glutathione biosynthesis and cytokinin signalling [155].

In an H. parasitica infection study in non-heading Chinese cabbage (B. campestris var. chinensis), a 2-DGE protein analysis and MALDI-TOF/TOF MS analysis along with transcript mRNA analysis using quantitative RT-PCR suggested a role for a $\mathrm{Ca}^{2+}$ signalling pathway as part of the ROS-mediated defence mechanism, with $39 \%$ of the genes having no correlation between protein and mRNA levels [156]. Studies have shown that proteomic data may not correlate with transcriptomic data measuring mRNA levels due to post-translational events and protein turnover $[155,156]$. To determine post-translational protein modification, an online 2D ion-exchange/reversed-phase HPLC method called Multidimensional Protein Identification Technology (MudPIT) can be used [157].

Time-course protein profiling in the pathosystem of B. juncea-Albugo candida successfully detected proteins that are differentially expressed in the resistant variety such as plant-thaumatin-like protein, superoxide dismutase, glutathione S-transferase, cysteine synthase and red chlorophyll catabolite reductase, suggesting ROS generation plays an important role in Brassica host resistance against this pathogen [158].

In a proteomic study applied to a non-pathogenic, arbuscular mycorrhizal fungal species, Piriformospora indica, studying the beneficial effect of the fungal endophyte on the B. napus host, liquid chromatography-mass spectrometry (LC-MS), coupled with bioinformatics, highlighted significant levels of differentially expressed proteins involved in the stress/defence response during the cell-death colonisation phase in the plant roots, elucidating the role of $P$. indica in enhancing B. napus resistance against abiotic and biotic stresses [159]. There is opportunity for the further characterisation of the genes that encode the stress-response proteins expressed in the B. napus-P. indica host symbiont relationship. This could be done through the physical mapping of the genes on the B. napus genome assemblies supplemented with transcriptome data. 


\section{Application of Omics Technologies in Brassica Pathogens}

\subsection{High-Quality Genome Assemblies}

High-quality reference genome assemblies for the major pathogens of Brassica are currently available, where long-read sequencing approaches such as ONT MinIon sequencing and PacBio sequencing were applied to assemble the genomes of L. maculans [160], S. sclerotiorum [161], A. brassicae [162] and A. alternata [163]. The genome of $P$. brassicae was assembled using Illumina Hiseq 2500 technology [164], while the A. candida genome was assembled using Roche/454 [165]; both are short-read sequencing technologies. These high-quality genome assemblies of the Brassica pathogens revealed that the fungal pathogens contain high genomic variation, including mutations largely induced by transposable elements (TE), large-scale chromosomal re-arrangements [166,167], presence-absence variation [168] and the gain or loss of accessory chromosomes [169-171]. These genetic events are continuously and actively evolving in the adaptive response to the selection pressure by the host plant resistance mechanism, thus generating high-genome-plasticity regions, which are often found distributed in compartments where most of the virulence genes are housed [172]. The extent of genetic divergence between individuals of the same fungal plant pathogen species is also high; hence, reference-based mapping is a challenge, although the diverged regions may not always be associated with virulence [173].

The availability of these high-quality genome assemblies has greatly facilitated the discovery of candidate genes for effectors and virulence factors and significantly advanced our understanding about the pathogen in relation to its evolutionary pattern and species diversity through comparative and population genomics studies $[137,168,174]$. Such deep molecular information will also allow us to uncover the complex Brassica-pathogen interactions, as these omics resources are routinely applied in plant pathology research.

\subsection{Transcriptomics of Virulence-Related Genes}

Transcriptome analysis has been increasingly applied to study pathogen gene expression during host invasion, allowing the real-time monitoring of the molecular mechanisms involved in pathogenesis. The recent genome-wide transcriptome analysis of Chittem, et al. [175] highlighted the involvement of peroxisome-related pathways, cell wall degradation by various enzymes and the detoxification of host metabolites as mechanisms of virulence by S. sclerotiorum towards B. napus. In the B. napus-L. maculans interaction, Haddadi, Larkan and Borhan [121] reported the upregulation of genes for fungal toxin biosynthesis during the necrotrophic stage of infection. Furthermore, several L. maculans effectors have been predicted from RNA-seq data, consistent with the results of Sonah, et al. [176], who detected different sets of genes coding for several effector proteins, where expression was correlated to L. maculans lifestyle transition from a biotrophic to necrotrophic stage. This observation provides an additional clue in deciphering the arsenal of virulence mechanisms employed by L. maculans, one of the most notoriously adaptive disease-causing pathogens of the Brassica family. In Clubroot, small secreted proteins (SSPbPs) have been identified that were assumed to play critical functions in primary and secondary infections, leading to hypertrophic tissue development $[177,178]$. For bacterial pathogens, such as X. campestris and P. carotovorum, a variety of mechanisms are deployed to evade host resistance including the release of extracellular enzymes such as cellulase, mannanase, pectinase, protease, polygalacturonases (PGs) and pectate lyase (Type II secretion system), the injection of effector proteins (Type III secretion system), as well as the production of exopolysaccharides and biofilm formation [179-181]. These virulence mechanisms can be manipulated by various techniques such as genome editing or developing cultivars that can undermine such mechanisms.

Through the in silico analysis of comparative genomic and transcriptomic data of S. sclerotiorum, 80 putative secondary metabolite gene clusters implicated in virulence in B. napus were identified in sub-telomeric regions close to transposable elements, with the upregulation of 12 polyketide synthases (PKSs) and enzymes during S. sclerotiorum infection of B. napus, revealing clues about 
the virulence pathway in the B. napus host [91]. Enzymes associated with secondary metabolites production in S. sclerotiorum to suppress host defence mechanisms, such as PKS, nonribosomal peptide synthase (NRPS) and chalcone synthase (CHS), were upregulated in an RNA-seq experiment studying B. napus-S. sclerotiorum disease resistance [182].

\subsection{Secretomics}

The fungal plant pathogen secretes a whole suite of proteins, collectively known as the secretome, during its interaction with the host [183]. The secretome comprises effector proteins and specific enzymes crucial for host colonisation, and the composition of each of these secreted proteins may vary between pathogen types based on the pathogen's mode of nutrition and lifestyle. The identification of these secreted proteins is key to understanding the pathogenicity process of the fungal plant pathogen in the host plant. The availability of rich omics resources and advanced bioinformatics pipelines for diverse fungal plant pathogen species have enabled the quick prediction of effector proteins across kingdom-wide fungal species with different lifestyles and have accelerated the cloning and functional characterisation of candidate effectors [184,185].

An understanding of the structural features of effector proteins, the diversity of the effector genes, and how these genes play a role in the pathogenicity and the evolutionary patterns of the genes are important for uncovering the complexity of the resistance mechanism in Brassica-pathogen interactions to support breeding resistant Brassica varieties [186]. Due to sequence diversity of effectors for avoiding recognition by the host immune system, the specific function and mechanism of effectors in inducing pathogenicity in the host are difficult to determine. However, the majority of effector genes can be predicted or identified more accurately and effectively based on the known characteristics of cloned effectors using improved computational, bioinformatics software combined with machine learning. Examples include EffectorP 2.0 [187,188], SignalP [189] and ApoplastP [190]. Bioinformatics tools specific for the identification of transposable elements (TEs) have also been developed [191]. Besides proteinaceous effector molecules, non-proteinaceous effectors in fungal pathogens, such as secondary metabolites, small noncoding RNAs and their biological roles in pathogenicity, have also been studied in plant-fungus interactions [192].

The conventional secretion pathway for the proteins during plant-pathogen interaction involves the endoplasmic reticulum-Golgi pathway $[193,194]$. However, increasing evidence has shown that some secretomes of plant or fungal/oomycete proteins are secreted independently of the classical pathway during plant-pathogen interactions. Hence, it is important that proteins lacking signal peptides within the fungal/oomycete secretome are not overlooked when identifying candidate effectors [195,196].

Some signalling molecules produced by phytopathogenic fungal species that play a part in virulence resemble homologous signalling molecules in the host, acting as mimics to evade the plant immune system for successful disease development [197]. For instance, oxylipins, which are important signalling molecules commonly found in animals, plants and fungi, play a role in growth, development and the defence response, with one of the examples being jasmonate [198]. In Brassica, oxylipins were found to display fungicidal activity against $A$. brassicae, L. maculans, S. sclerotiorum and Verticillium longisporum [199]. In phytopathogenic fungi, oxylipins have been found to be involved in disease progression through the modification of the plant host defence mechanisms [200,201], an example being F. oxysporum hijacking the oxylipin JA signalling pathway in $A$. thaliana [202].

The gene expression profile from the $P$. brassicae $\mathrm{Pb} 3$ genome assembly revealed that the pathogen contains genes that are associated with the biosynthesis of the plant hormones cytokinin and auxin, suggesting a potential role for these hormones in virulence activity in the host plant [203], while gene clusters for the synthesis of the ABA hormone were detected in L. maculans, suggesting a putative role of ABA production in disease progression in B. napus [204]. One of the well-characterised effectors for P. brassicae is the benzoic acid (BA)/SA methyltransferase protein (PbBSMT), which suppresses host SA signalling during plant defence [177]. The functional role of PbBSMT is similar to that of 
the SABATH methyltransferase gene family in A. thaliana, AtBSMT1, where the genes play a role in converting SA into methyl salicylate (MeSA), which is the inactive form of SA, thereby compromising the SAR defence response [205]. A transcriptomic study of P. brassicae infection in Kohlrabi (B. oleracea var. gongylodes) showed that PbBSMT was one of the highest-expressed pathogen genes in the root gall tissue, playing a role in the local reduction of SA via PbBMST-mediated methylation [206]. It was found from another cloning experiment with AtBSMT1 vs. PbBSMT in P. brassicae-infected Arabidopsis (host) and A. candida-infected Arabidopsis (non-host), comparing the level of SA inactivation in Arabidopsis, that $P b B S M T$ resulted in higher levels of SA inactivation, meaning PbBSMT suppressed the host and non-host SAR defence mechanisms at a greater level [206,207]. Multi-omics approaches combining genomics, transcriptomics, proteomics and metabolomics using computational strategies will allow us to identify suitable mimicking molecules in the fungal and/or host species that trigger stronger plant defence systems during plant-pathogen interactions [208].

Beneficial bacterial endophytes found in the apoplast region of $B$. napus have been shown to inhibit the growth of X. campestris, S. sclerotiorum and L. maculans, thus acting as natural biological control against $B$. napus diseases [209]. The high-throughput sequencing of the fungal endophytes obtained from healthy roots of tumorous stem mustard (B. juncea var. tumida) and P. brassicae-infected roots of the same plant species showed a more diverse composition of the fungal endophytes in the healthy roots compared to in the diseased roots. This suggests a strong interaction network in the fungal endophyte community that contributes towards the optimum health of the host plant [210]. A combination of secretomic and proteomic analysis of the apoplast fluids will allow us to identify and characterise the diverse apoplast proteins and further elucidate their role in protecting $B$. napus from pathogen invasion.

\subsection{Interactome}

Interactomics is the study of networks of gene and protein interactions in biological systems [211]. Understanding the biological process and pathogenicity mechanisms of the fungal pathogens in Brassica crops is crucial for the identification of disease resistance targets. A web-based database called the Pathogen-Host Interactions database (PHI-base) has been set up that stores curated experimental data obtained from host-pathogen studies, encompassing phenotypic data and biological data on pathogenicity, virulence, and effector gene functions from fungal, oomycete and bacterial pathogens from animal, plant, fungal and insect host species, with embedded search links including BLAST, PubMed, UniProt Knowledgebase and others [212]. Complementing PHI-base, PHI-Nets provides information related to networks of molecular and biological protein-protein interactions for the understanding of pathogenicity and virulence mechanisms in host-pathogen relationships [213].

\section{Application of Metabolomics and Systems Biology in the Brassica-Pathogen System}

Metabolomics in plant pathology refers to the study of host plant metabolism changes in response to pathogen infection that provides an understanding of how host-pathogen interaction, through a (de)activation of metabolites and associated signalling pathways, could lead towards a resistant or susceptible outcome for the host [214]. Metabolites associated with black rot infection in B. oleracea were identified using liquid chromatography-quadrupole time-of-flight (LC-QTOF)-based metabolite profiling, which revealed that metabolic changes in the host occurred $48 \mathrm{~h}$ after infection and implicated photosynthesis, alkaloids, coumarins and sphingolipids as involved during the infection process [215]. Systems biology was constructed to model the metabolic pathway for JA signalling in the Brassica-Alternaria pathophysiology to identify important elements in the regulation of resistance mechanisms and to pinpoint molecular targets for engineering enhanced resistance in Brassica crops [216].

The huge number of data collected from multi-omics technologies will be useful in the construction of network biology, where mathematical models and computational approaches are implemented to predict the pathogenicity and virulence mechanisms in plant-pathogen interactions [217]. Metabolic 
pathways supported by mathematical modelling can be used to study how cells within a multicellular organism work cooperatively to carry out a particular function. An example of systems biology was carried out for a A. thaliana-S. sclerotiorum pathosystem, where a genome-scale metabolic model of $S$. sclerotiorum based on global gene expression was constructed to assess the metabolic activity in different parts of the hyphal cells, supporting the hypothesis that cooperation in S. sclerotiorum hyphal cells is necessary for virulence and host colonisation [218]. A combination of metabolomics with quantitative genetics was used to discover the potential role of gluconasturtiin in the B. napus resistance response against Clubroot and the underlying QTL controlling the trait on chromosome C03 and C09 [219]. Gluconasturtiin is a type of glucosinolate compound associated with the biotic resistance responses of Brassica species [220]. An example of using multi-omics supplemented with functional studies to discover key resistance pathways involved the soybean-S. sclerotiorum pathosystem, where the induction of JA signalling, elevated ROS control and reprogramming of the phenylpropanoid pathway have been suggested to be an important resistance mechanism [221]. Many more novel plant-pathogen interactions in the Brassica pathosystems could be discovered through the application of multi-omics technologies (Figure 2).

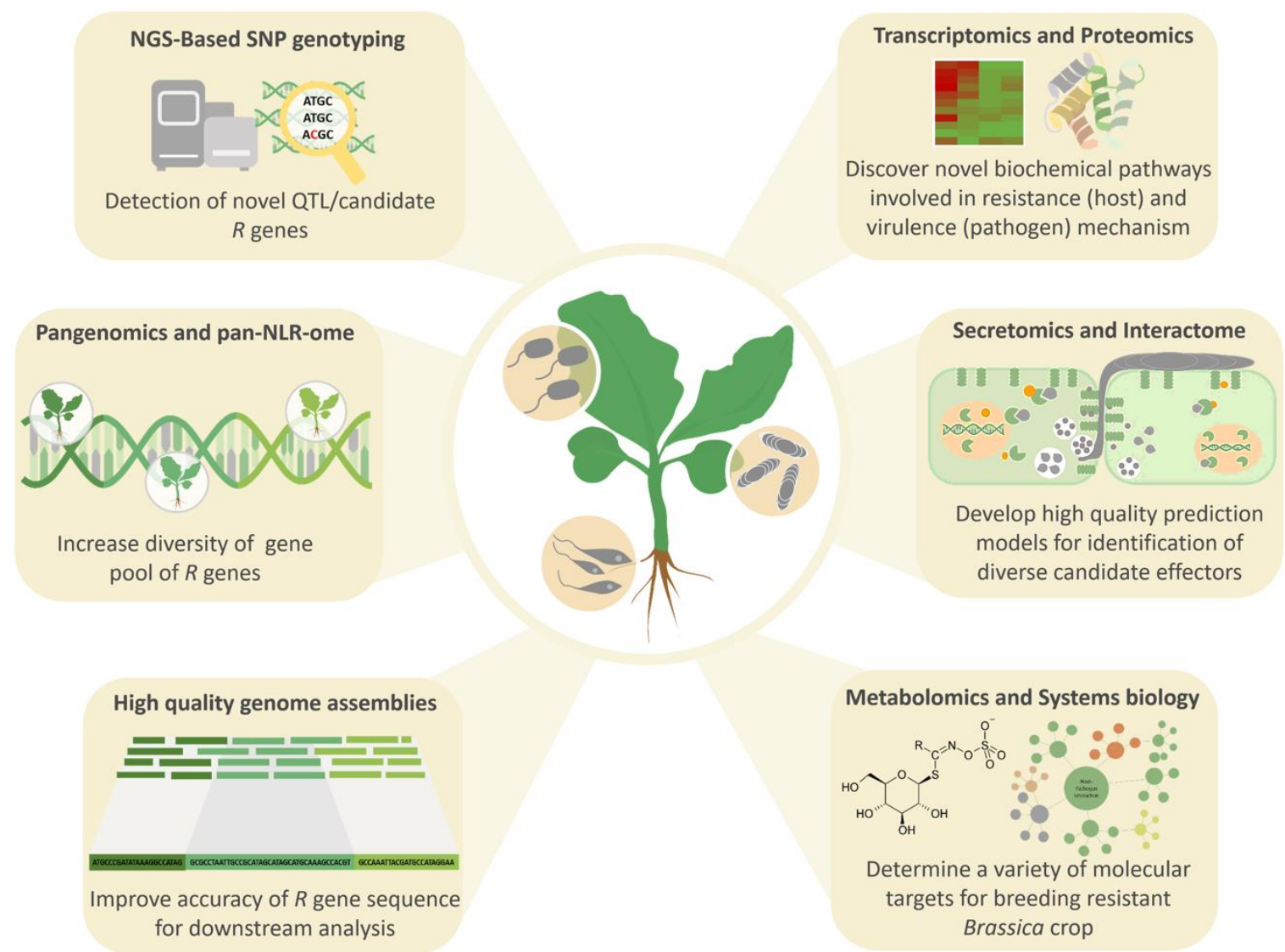

Figure 2. The application of multi-omics technologies in the discovery of novel plant-pathogen interactions in the Brassica pathosystems.

\section{Future Perspectives}

Genomics-assisted breeding, also known as genomic selection, is an advanced level of omics breeding in Brassica crops. Genomic selection incorporating multiple traits in crop breeding programs, with a focus on biotic stress, not only offers a promising strategy for developing high-quality Brassica crops resilient against a wide variety of pathogen types, but does so without compromising yield or crop quality [222,223]. A further area of interest is to screen for favourable alleles of diverse resistance genes sourced from wild relatives of Brassica species or, beyond that, wider members of the Brassicaceae 
family and expand from disease resistance genes to regulators such as small RNAs to find out how the disease resistance gene expression is being regulated [224].

Beyond the gene level, a wider perspective on how epigenetics affects plant responses towards pathogen attack should be considered to enhance our understanding about the resistance mechanisms in Brassica. Examples include how TEs, which are associated with DNA methylation, might contribute towards the resistance and susceptibility of the Brassica crop $[225,226]$ and how epigenetic variability is linked to phenotypic responses towards plant pathogens, as shown in the Arabidopsis-P. brassicae pathosystem, where DNA methylation contributes towards quantitative resistance to Clubroot, based on epigenotyped epigenetic recombinant inbred lines [227]. In the B. napus-L. maculans pathosystem, promoters of defence genes were differentially methylated during the early stages of infection in the resistant host cultivar compared to the susceptible cultivar [228]. From the pathogen perspective, the availability of the multi-omics data is useful for screening candidate pathogenicity genes in the pathogen. However, this is dependent upon the race classification keeping pace with the omics data of the fungal/oomycete pathogens becoming available; otherwise, an effective application of the pathogenicity genes in field populations cannot be achieved [229].

Functional analysis of candidate genes in the Brassica-pathogen system can be performed using the clustered, regularly interspaced, palindromic repeats (CRISPR)-Cas9 (CRISPR-associated protein 9) system. In B. napus, two genes, BnWRKY11 and BnWRKY70, that encode for WRKY transcription factors were successfully knocked out using CRISPR-Cas9, showing the latter gene regulates disease resistance to S. sclerotiorum [230]. This multiplex gene knock-out study is very useful for gene functional studies in polyploid crops such as Brassica that contain many copies of the same genes as homeologs within the genome. The CRISPR-Cas9 system was also successfully applied in B. rapa for early-flowering trait genome editing [231]. In L. maculans, the chitin-binding gene LmCBP1, which was highly expressed during infection in B. napus and functional analysis using CRISPR-Cas9, was shown to play a role in enhancing cell death for pathogen growth and also to be involved in tolerance towards $\mathrm{H}_{2} \mathrm{O}_{2}$ during the plant immune response [232].

\section{Conclusions}

The omics tools have advanced our understanding of Brassica-pathogen interactions in many ways and will become the mainstream approach to rapidly identifying QTL/candidate $R /$ pathogenicity genes for breeding superior Brassica crop species that are resistant towards the main pathogen types discussed in this review. Using the various omics or multi-omics tools, supplemented with further fine tuning of the bioinformatics methods, will not only speed up the screening of favourable alleles in Brassica germplasm promoting resistance against the major pathogens, but also expediate the identification and cloning of favourable genes with increased precision. Together, this will foster success in the breeding of improved and/or new varieties of Brassica crops for sustainable agriculture [233].

Author Contributions: T.X.N., J.A. and J.B. conceived the idea; T.X.N. and J.A. wrote the original draft; T.X.N., J.A., M.B., D.E., J.B. reviewed and edited the manuscript. All authors approved the final version of the manuscript. All authors have read and agreed to the published version of the manuscript.

Funding: This work was funded by the Australian Research Council Projects DP1601004497 and DP200100762.

Conflicts of Interest: The authors declare no conflict of interests.

\section{References}

1. Kandel, S.L.; Joubert, P.M.; Doty, S.L. Bacterial endophyte colonization and distribution within plants. Microorganisms 2017, 5, 77. [CrossRef] [PubMed]

2. Spanu, P.D.; Panstruga, R. Editorial: Biotrophic plant-microbe interactions. Front. Plant Sci. 2017, 8, 192. [CrossRef] [PubMed]

3. Abramovitch, R.B.; Anderson, J.C.; Martin, G.B. Bacterial elicitation and evasion of plant innate immunity. Nat. Rev. Mol. Cell Biol. 2006, 7, 601-611. [CrossRef] [PubMed] 
4. Dodds, P.N.; Rathjen, J.P. Plant immunity: Towards an integrated view of plant-pathogen interactions. Nat. Rev. Genet. 2010, 11, 539-548. [CrossRef] [PubMed]

5. Lo Presti, L.; Lanver, D.; Schweizer, G.; Tanaka, S.; Liang, L.; Tollot, M.; Zuccaro, A.; Reissmann, S.; Kahmann, R. Fungal effectors and plant susceptibility. Annu. Rev. Plant Biol. 2015, 66, 513-545. [CrossRef] [PubMed]

6. Jones, J.D.G.; Dangl, J.L. The plant immune system. Nature 2006, 444, 323-329. [CrossRef] [PubMed]

7. Stotz, H.U.; Mitrousia, G.K.; de Wit, P.J.G.M.; Fitt, B.D.L. Effector-triggered defence against apoplastic fungal pathogens. Trends Plant Sci. 2014, 19, 491-500. [CrossRef]

8. Cook, D.E.; Mesarich, C.H.; Thomma, B.P.H.J. Understanding plant immunity as a surveillance system to detect invasion. Annu. Rev. Phytopathol. 2015, 53, 541-563. [CrossRef]

9. Van der Burgh, A.M.; Joosten, M.H.A.J. Plant immunity: Thinking outside and inside the box. Trends Plant Sci. 2019, 24, 587-601. [CrossRef]

10. Kanyuka, K.; Rudd, J.J. Cell surface immune receptors: The guardians of the plant's extracellular spaces. Curr. Opin. Plant Biol. 2019, 50, 1-8. [CrossRef]

11. Hohmann, N.; Wolf, E.M.; Lysak, M.A.; Koch, M.A. A time-calibrated road map of Brassicaceae species radiation and evolutionary history. Plant Cell 2015, 27, 2770-2784. [CrossRef] [PubMed]

12. Kiefer, M.; Schmickl, R.; German, D.A.; Mandáková, T.; Lysak, M.A.; Al-Shehbaz, I.A.; Franzke, A.; Mummenhoff, K.; Stamatakis, A.; Koch, M.A. BrassiBase: Introduction to a novel knowledge database on Brassicaceae evolution. Plant Cell Physiol. 2014, 55, e3. [CrossRef] [PubMed]

13. Schiessl, S.V.; Mason, A. Ancient and recent polyploid evolution in Brassica. In Brassica Improvement-Molecular, Genetics and Genomic Perspectives; Wani, S.H., Thakur, A.K., Jeshima Khan, Y., Eds.; Springer: Cham, Switzerland, 2020; pp. 49-66. [CrossRef]

14. Friedt, W.; Tu, J.; Fu, T. Academic and economic importance of Brassica napus rapeseed. In The Brassica napus Genome; Liu, S., Snowdon, R., Chalhoub, B., Eds.; Springer International Publishing: Cham, Switzerland, 2018. [CrossRef]

15. Cheng, F.; Wu, J.; Wang, X. Genome triplication drove the diversification of Brassica plants. Hortic. Res. 2014, 1, 14024. [CrossRef]

16. Cheng, F.; Sun, R.; Hou, X.; Zheng, H.; Zhang, F.; Zhang, Y.; Liu, B.; Liang, J.; Zhuang, M.; Liu, Y.; et al. Subgenome parallel selection is associated with morphotype diversification and convergent crop domestication in Brassica rapa and Brassica oleracea. Nat. Genet. 2016, 48, 1218-1224. [CrossRef] [PubMed]

17. Werner, C.; Snowdon, R. Genome-facilitated breeding of oilseed rape. In The Brassica napus Genome; Liu, S., Snowdon, R., Chalhoub, B., Eds.; Springer International Publishing: Cham, Switzerland, 2018; pp. 245-269. [CrossRef]

18. FAO Stat. Food and Agriculture Organization of the United Nations-Statistics Division, Crop. Available online: http://www.fao.org/faostat/en/\#data/QC (accessed on 31 January 2020).

19. Varshney, R.K.; Roorkiwal, M.; Sorrells, M.E. Genomic selection for crop improvement: An introduction. In Genomic Selection for Crop Improvement: New Molecular Breeding Strategies for Crop Improvement; Varshney, R.K., Roorkiwal, M., Sorrells, M.E., Eds.; Springer International Publishing: Cham, Switzerland, 2017; pp. 1-6. [CrossRef]

20. Anderson, R.; Bayer, P.E.; Edwards, D. Climate change and the need for agricultural adaptation. Curr. Opin. Plant Biol. 2020, 56, 197-202. [CrossRef]

21. Kabbage, M.; Yarden, O.; Dickman, M.B. Pathogenic attributes of Sclerotinia sclerotiorum: Switching from a biotrophic to necrotrophic lifestyle. Plant Sci. 2015, 233, 53-60. [CrossRef]

22. Neik, T.X.; Barbetti, M.J.; Batley, J. Current status and challenges in identifying disease resistance genes in Brassica napus. Front. Plant Sci. 2017, 8, 1788. [CrossRef]

23. Lv, H.; Fang, Z.; Yang, L.; Zhang, Y.; Wang, Y. An update on the arsenal: Mining resistance genes for disease management of Brassica crops in the genomic era. Hortic. Res. 2020, 7, 34. [CrossRef]

24. Zhang, X.; Fernando, W.G.D. Insights into fighting against blackleg disease of Brassica napus in Canada. Crop. Pasture Sci. 2017, 69, 40-47. [CrossRef]

25. Hwang, S.-F.; Strelkov, S.E.; Peng, G.; Ahmed, H.; Zhou, Q.; Turnbull, G. Blackleg (Leptosphaeria maculans) severity and yield loss in canola in Alberta, Canada. Plants 2016, 5, 31. [CrossRef]

26. Strehlow, B.; de Mol, F.; Struck, C. Risk potential of Clubroot disease on winter oilseed rape. Plant Dis. 2014, 99, 667-675. [CrossRef] [PubMed] 
27. Khan, M.A.; Cowling, W.; Banga, S.S.; You, M.P.; Tyagi, V.; Bharti, B.; Barbetti, M.J. Patterns of inheritance for cotyledon resistance against Sclerotinia sclerotiorum in Brassica napus. Euphytica 2020, 216, 79. [CrossRef]

28. Al-Lami, H.F.D.; You, M.P.; Barbetti, M.J. Role of foliage component and host age on severity of Alternaria leaf spot (caused by Alternaria japonica and A. brassicae) in canola (Brassica napus) and mustard (B. juncea) and yield loss in canola. Crop. Pasture Sci. 2019, 70, 969-980. [CrossRef]

29. Mohammed, A.E.; You, M.P.; Banga, S.S.; Barbetti, M.J. Resistances to downy mildew (Hyaloperonospora brassicae) in diverse Brassicaceae offer new disease management opportunities for oilseed and vegetable crucifer industries. Eur. J. Plant Pathol. 2019, 153, 915-929. [CrossRef]

30. Bailey-Serres, J.; Parker, J.E.; Ainsworth, E.A.; Oldroyd, G.E.D.; Schroeder, J.I. Genetic strategies for improving crop yields. Nature 2019, 575, 109-118. [CrossRef]

31. Bayer, P.E.; Hurgobin, B.; Golicz, A.A.; Chan, C.K.K.; Yuan, Y.; Lee, H.; Renton, M.; Meng, J.; Li, R.; Long, Y.; et al. Assembly and comparison of two closely related Brassica napus genomes. Plant Biotechnol. J. 2017, 15, 1602-1610. [CrossRef]

32. Sun, F.; Fan, G.; Hu, Q.; Zhou, Y.; Guan, M.; Tong, C.; Li, J.; Du, D.; Qi, C.; Jiang, L.; et al. The high-quality genome of Brassica napus cultivar 'ZS11' reveals the introgression history in semi-winter morphotype. Plant J. 2017, 92, 452-468. [CrossRef]

33. Lee, H.; Chawla, H.S.; Obermeier, C.; Dreyer, F.; Abbadi, A.; Snowdon, R. Chromosome-scale assembly of winter oilseed rape Brassica napus. Front. Plant Sci. 2020, 11, 496. [CrossRef]

34. Roberts, R.J.; Carneiro, M.O.; Schatz, M.C. The advantages of SMRT sequencing. Genome Biol. 2013, 14, 405. [CrossRef]

35. Jain, M.; Olsen, H.E.; Paten, B.; Akeson, M. The Oxford Nanopore MinION: Delivery of nanopore sequencing to the genomics community. Genome Biol. 2016, 17, 239. [CrossRef]

36. Howe, K.; Wood, J.M.D. Using optical mapping data for the improvement of vertebrate genome assemblies. GigaScience 2015, 4, 10. [CrossRef] [PubMed]

37. Li, C.; Lin, F.; An, D.; Wang, W.; Huang, R. Genome sequencing and assembly by long reads in plants. Genes 2017, 9, 6. [CrossRef] [PubMed]

38. Van Berkum, N.L.; Lieberman-Aiden, E.; Williams, L.; Imakaev, M.; Gnirke, A.; Mirny, L.A.; Dekker, J.; Lander, E.S. Hi-C: A method to study the three-dimensional architecture of genomes. J. Vis. Exp. 2010, 6, 1869. [CrossRef] [PubMed]

39. Zhang, L.; Cai, X.; Wu, J.; Liu, M.; Grob, S.; Cheng, F.; Liang, J.; Cai, C.; Liu, Z.; Liu, B.; et al. Improved Brassica rapa reference genome by single-molecule sequencing and chromosome conformation capture technologies. Hortic. Res. 2018, 5, 50. [CrossRef] [PubMed]

40. Sun, D.; Wang, C.; Zhang, X.; Zhang, W.; Jiang, H.; Yao, X.; Liu, L.; Wen, Z.; Niu, G.; Shan, X. Draft genome sequence of cauliflower (Brassica oleracea L. var. botrytis) provides new insights into the $C$ genome in Brassica species. Hortic. Res. 2019, 6, 82. [CrossRef]

41. Rousseau-Gueutin, M.; Belser, C.; Silva, C.D.; Richard, G.; Istace, B.; Cruaud, C.; Falentin, C.; Boideau, F.; Boutte, J.; Delourme, R.; et al. Long-reads assembly of the Brassica napus; reference genome, Darmor-bzh. bioRxiv 2020. [CrossRef]

42. Schiessl, S.-V.; Katche, E.; Ihien, E.; Chawla, H.S.; Mason, A.S. The role of genomic structural variation in the genetic improvement of polyploid crops. Crop J. 2019, 7, 127-140. [CrossRef]

43. Bayer, P.E.; Golicz, A.A.; Tirnaz, S.; Chan, C.-K.K.; Edwards, D.; Batley, J. Variation in abundance of predicted resistance genes in the Brassica oleracea pangenome. Plant Biotechnol. J. 2019, 17, 789-800. [CrossRef]

44. Hurgobin, B.; Golicz, A.A.; Bayer, P.E.; Chan, C.-K.K.; Tirnaz, S.; Dolatabadian, A.; Schiessl, S.V.; Samans, B.; Montenegro, J.D.; Parkin, I.A.P.; et al. Homoeologous exchange is a major cause of gene presence/absence variation in the amphidiploid Brassica napus. Plant Biotechnol. J. 2018, 16, 1265-1274. [CrossRef]

45. Dolatabadian, A.; Bayer, P.E.; Tirnaz, S.; Hurgobin, B.; Edwards, D.; Batley, J. Characterization of disease resistance genes in the Brassica napus pangenome reveals significant structural variation. Plant Biotechnol. J. 2019, 18, 969-982. [CrossRef]

46. Belser, C.; Istace, B.; Denis, E.; Dubarry, M.; Baurens, F.-C.; Falentin, C.; Genete, M.; Berrabah, W.; Chèvre, A.-M.; Delourme, R.; et al. Chromosome-scale assemblies of plant genomes using nanopore long reads and optical maps. Nat. Plants 2018, 4, 879-887. [CrossRef] [PubMed] 
47. Parkin, I.A.P.; Koh, C.; Tang, H.; Robinson, S.J.; Kagale, S.; Clarke, W.E.; Town, C.D.; Nixon, J.; Krishnakumar, V.; Bidwell, S.L.; et al. Transcriptome and methylome profiling reveals relics of genome dominance in the mesopolyploid Brassica oleracea. Genome Biol. 2014, 15, R77. [CrossRef] [PubMed]

48. Tirnaz, S.; Edwards, D.; Batley, J. The importance of plant pan-genomes in breeding. In Quantitative Genetics, Genomics and Plant Breeding, 2nd ed.; Kang, M.S., Ed.; CABI: Boston, MA, USA, 2020; pp. 27-32. [CrossRef]

49. Tao, Y.; Zhao, X.; Mace, E.; Henry, R.; Jordan, D. Exploring and exploiting pan-genomics for crop improvement. Mol. Plant 2019, 12, 156-169. [CrossRef] [PubMed]

50. Bayer, P.E.; Golicz, A.A.; Scheben, A.; Batley, J.; Edwards, D. Plant pan-genomes are the new reference. Nat. Plants 2020, 6, 914-920. [CrossRef]

51. Song, J.-M.; Guan, Z.; Hu, J.; Guo, C.; Yang, Z.; Wang, S.; Liu, D.; Wang, B.; Lu, S.; Zhou, R.; et al. Eight high-quality genomes reveal pan-genome architecture and ecotype differentiation of Brassica napus. Nat. Plants 2020, 6, 34-45. [CrossRef]

52. Golicz, A.A.; Bayer, P.E.; Barker, G.C.; Edger, P.P.; Kim, H.; Martinez, P.A.; Chan, C.K.K.; Severn-Ellis, A.; McCombie, W.R.; Parkin, I.A.P.; et al. The pangenome of an agronomically important crop plant Brassica oleracea. Nat. Commun. 2016, 7, 13390. [CrossRef]

53. Amsbury, S. Sensing attack: The role of wall-associated kinases in plant pathogen responses. Plant Physiol. 2020, 183, 1420. [CrossRef]

54. Tirnaz, S.; Bayer, P.; Inturrisi, F.; Zhang, F.; Yang, H.; Dolatabadian, A.; Neik, T.X.; Severn-Ellis, A.; Patel, D.; Ibrahim, M.I.; et al. Resistance gene analogs in the Brassicaceae: Identification, characterization, distribution, and evolution. Plant Physiol. 2020, 184, 909-922. [CrossRef]

55. Khan, A.W.; Garg, V.; Roorkiwal, M.; Golicz, A.A.; Edwards, D.; Varshney, R.K. Super-pangenome by integrating the wild side of a species for accelerated crop improvement. Trends Plant Sci. 2020, 25, 148-158. [CrossRef]

56. Perumal, S.; Koh, C.S.; Jin, L.; Buchwaldt, M.; Higgins, E.E.; Zheng, C.; Sankoff, D.; Robinson, S.J.; Kagale, S.; Navabi, Z.-K.; et al. A high-contiguity Brassica nigra genome localizes active centromeres and defines the ancestral Brassica genome. Nat. Plants 2020, 6, 929-941. [CrossRef]

57. Lin, K.; Zhang, N.; Severing, E.I.; Nijveen, H.; Cheng, F.; Visser, R.G.F.; Wang, X.; de Ridder, D.; Bonnema, G. Beyond genomic variation-Comparison and functional annotation of three Brassica rapa genomes: A turnip, a rapid cycling and a Chinese cabbage. BMC Genom. 2014, 15, 250. [CrossRef] [PubMed]

58. Delourme, R.; Laperche, A.; Bouchet, A.-S.; Jubault, M.; Paillard, S.; Manzanares-Dauleux, M.-J.; Nesi, N. Genes and quantitative trait loci mapping for major agronomic traits in Brassica napus L. In The Brassica napus Genome; Liu, S., Snowdon, R., Chalhoub, B., Eds.; Springer International Publishing: Cham, Switzerland, 2018; pp. 41-85. [CrossRef]

59. Nadeem, M.A.; Nawaz, M.A.; Shahid, M.Q.; Doğan, Y.; Comertpay, G.; Yıldız, M.; Hatipoğlu, R.; Ahmad, F.; Alsaleh, A.; Labhane, N.; et al. DNA molecular markers in plant breeding: Current status and recent advancements in genomic selection and genome editing. Biotechnol. Biotechnol. Equip. 2018, 32, 261-285. [CrossRef]

60. Nguyen, K.L.; Grondin, A.; Courtois, B.; Gantet, P. Next-generation sequencing accelerates crop gene discovery. Trends Plant Sci. 2019, 24, 263-274. [CrossRef]

61. Singh, B.D.; Singh, A.K. High-throughput SNP genotyping. In Marker-Assisted Plant Breeding: Principles and Practices; Singh, B.D., Singh, A.K., Eds.; Springer India: New Delhi, India, 2015; pp. 367-400. [CrossRef]

62. Mammadov, J.; Aggarwal, R.; Buyyarapu, R.; Kumpatla, S. SNP markers and their impact on plant breeding. Int. J. Plant Genom. 2012, 2012, 728398. [CrossRef] [PubMed]

63. Scheben, A.; Batley, J.; Edwards, D. Genotyping-by-sequencing approaches to characterize crop genomes: Choosing the right tool for the right application. Plant Biotechnol. J. 2017, 15, 149-161. [CrossRef]

64. Yu, X.; Wang, H.; Zhong, W.; Bai, J.; Liu, P.; He, Y. QTL mapping of leafy heads by genome resequencing in the RIL population of Brassica rapa. PLoS ONE 2013, 8, e76059. [CrossRef] [PubMed]

65. Elshire, R.J.; Glaubitz, J.C.; Sun, Q.; Poland, J.A.; Kawamoto, K.; Buckler, E.S.; Mitchell, S.E. A robust, simple Genotyping-by-sequencing (GBS) approach for high diversity species. PLoS ONE 2011, 6, e19379. [CrossRef]

66. Chung, Y.S.; Choi, S.C.; Jun, T.-H.; Kim, C. Genotyping-by-sequencing: A promising tool for plant genetics research and breeding. Hortic. Environ. Biotechnol. 2017, 58, 425-431. [CrossRef]

67. Ott, A.; Liu, S.; Schnable, J.C.; Yeh, C.-T.E.; Wang, K.-S.; Schnable, P.S. tGBS ${ }^{\circledR}$ genotyping-by-sequencing enables reliable genotyping of heterozygous loci. Nucleic Acids Res. 2017, 45, e178. [CrossRef] 
68. Clarke, W.E.; Higgins, E.E.; Plieske, J.; Wieseke, R.; Sidebottom, C.; Khedikar, Y.; Batley, J.; Edwards, D.; Meng, J.; Li, R.; et al. A high-density SNP genotyping array for Brassica napus and its ancestral diploid species based on optimised selection of single-locus markers in the allotetraploid genome. Theor. Appl. Genet. 2016, 129, 1887-1899. [CrossRef]

69. You, Q.; Yang, X.; Peng, Z.; Xu, L.; Wang, J. Development and applications of a high throughput genotyping tool for polyploid crops: Single Nucleotide Polymorphism (SNP) array. Front. Plant Sci. 2018, 9, 104. [CrossRef] [PubMed]

70. Mason, A.S.; Zhang, J.; Tollenaere, R.; Vasquez Teuber, P.; Dalton-Morgan, J.; Hu, L.; Yan, G.; Edwards, D.; Redden, R.; Batley, J. High-throughput genotyping for species identification and diversity assessment in germplasm collections. Mol. Ecol. Resour. 2015, 15, 1091-1101. [CrossRef] [PubMed]

71. Scheben, A.; Verpaalen, B.; Lawley, C.T.; Chan, C.-K.K.; Bayer, P.E.; Batley, J.; Edwards, D. CropSNPdb: A database of SNP array data for Brassica crops and hexaploid bread wheat. Plant J. 2019, 98, 142-152. [CrossRef]

72. Raman, H.; Raman, R.; Coombes, N.; Song, J.; Diffey, S.; Kilian, A.; Lindbeck, K.; Barbulescu, D.M.; Batley, J.; Edwards, D.; et al. Genome-wide association study identifies new loci for resistance to Leptosphaeria maculans in canola. Front. Plant Sci. 2016, 7, 1513. [CrossRef] [PubMed]

73. Fu, F.; Zhang, X.; Liu, F.; Peng, G.; Yu, F.; Fernando, D. Identification of resistance loci in Chinese and Canadian canola/rapeseed varieties against Leptosphaeria maculans based on Genome-Wide Association Studies. BMC Genom. 2020, 21, 501. [CrossRef] [PubMed]

74. Wu, J.; Zhao, Q.; Liu, S.; Shahid, M.; Lan, L.; Cai, G.; Zhang, C.; Fan, C.; Wang, Y.; Zhou, Y. Genome-wide association study identifies new loci for resistance to Sclerotinia Stem Rot in Brassica napus. Front. Plant Sci. 2016, 7, 1418. [CrossRef] [PubMed]

75. Atri, C.; Akhatar, J.; Gupta, M.; Gupta, N.; Goyal, A.; Rana, K.; Kaur, R.; Mittal, M.; Sharma, A.; Singh, M.P.; et al. Molecular and genetic analysis of defensive responses of Brassica juncea-B. fruticulosa introgression lines to Sclerotinia infection. Sci. Rep. 2019, 9, 17089. [CrossRef]

76. Rana, K.; Atri, C.; Akhatar, J.; Kaur, R.; Goyal, A.; Singh Mohini, P.; Kumar, N.; Sharma, A.; Sandhu Prabhjodh, S.; Kaur, G.; et al. Detection of first marker trait associations for resistance against Sclerotinia sclerotiorum in Brassica juncea-Erucastrum cardaminoides introgression lines. Front. Plant Sci. 2019, 10, 1015. [CrossRef]

77. Li, L.; Luo, Y.; Chen, B.; Xu, K.; Zhang, F.; Li, H.; Huang, Q.; Xiao, X.; Zhang, T.; Hu, J.; et al. A genome-wide association study reveals new loci for resistance to clubroot disease in Brassica napus. Front. Plant Sci. 2016, 7, 1483. [CrossRef]

78. Peng, L.; Zhou, L.; Li, Q.; Wei, D.; Ren, X.; Song, H.; Mei, J.; Si, J.; Qian, W. Identification of quantitative trait loci for Clubroot resistance in Brassica oleracea with the use of Brassica SNP microarray. Front. Plant Sci. 2018, 9, 822. [CrossRef]

79. Laila, R.; Park, J.-I.; Robin, A.H.K.; Natarajan, S.; Vijayakumar, H.; Shirasawa, K.; Isobe, S.; Kim, H.-T.; Nou, I.-S. Mapping of a novel clubroot resistance QTL using ddRAD-seq in Chinese cabbage (Brassica rapa L.). BMC Plant Biol. 2019, 19, 13. [CrossRef] [PubMed]

80. Mei, J.; Shao, C.; Yang, R.; Feng, Y.; Gao, Y.; Ding, Y.; Li, J.; Qian, W. Introgression and pyramiding of genetic loci from wild Brassica oleracea into B. napus for improving Sclerotinia resistance of rapeseed. Theor. Appl. Genet. 2020, 133, 1313-1319. [CrossRef] [PubMed]

81. Gabur, I.; Chawla, H.S.; Lopisso, D.T.; von Tiedemann, A.; Snowdon, R.J.; Obermeier, C. Gene presence-absence variation associates with quantitative Verticillium longisporum disease resistance in Brassica napus. Sci. Rep. 2020, 10, 4131. [CrossRef] [PubMed]

82. Wu, D.; Liang, Z.; Yan, T.; Xu, Y.; Xuan, L.; Tang, J.; Zhou, G.; Lohwasser, U.; Hua, S.; Wang, H.; et al. Whole-genome resequencing of a worldwide collection of rapeseed accessions reveals the genetic basis of ecotype divergence. Mol. Plant 2019, 12, 30-43. [CrossRef]

83. Lu, K.; Wei, L.; Li, X.; Wang, Y.; Wu, J.; Liu, M.; Zhang, C.; Chen, Z.; Xiao, Z.; Jian, H.; et al. Whole-genome resequencing reveals Brassica napus origin and genetic loci involved in its improvement. Nat. Commun. 2019, 10, 1154. [CrossRef]

84. Lee, J.; Izzah, N.K.; Jayakodi, M.; Perumal, S.; Joh, H.J.; Lee, H.J.; Lee, S.-C.; Park, J.Y.; Yang, K.-W.; Nou, I.-S.; et al. Genome-wide SNP identification and QTL mapping for black rot resistance in cabbage. BMC Plant Biol. 2015, 15, 32. [CrossRef] 
85. Farid, M.; Yang, R.-C.; Kebede, B.; Rahman, H. Evaluation of Brassica oleracea accessions for resistance to Plasmodiophora brassicae and identification of genomic regions associated with resistance. Genome 2019, 63, 91-101. [CrossRef]

86. Wei, D.; Cui, Y.; He, Y.; Xiong, Q.; Qian, L.; Tong, C.; Lu, G.; Ding, Y.; Li, J.; Jung, C.; et al. A genome-wide survey with different rapeseed ecotypes uncovers footprints of domestication and breeding. J. Exp. Bot. 2017, 68, 4791-4801. [CrossRef]

87. Larkan, N.J.; Yu, F.; Lydiate, D.J.; Rimmer, S.R.; Borhan, M.H. Single R gene introgression lines for accurate dissection of the Brassica-Leptosphaeria pathosystem. Front. Plant Sci. 2016, 7, 1771. [CrossRef]

88. Ferdous, M.J.; Hossain, M.R.; Park, J.-I.; Robin, A.H.K.; Natarajan, S.; Jesse, D.M.I.; Jung, H.-J.; Kim, H.-T.; Nou, I.-S. In-silico identification and differential expressions of LepR4-syntenic disease resistance related domain containing genes against Blackleg causal fungus Leptosphaeria maculans in Brassica oleracea. Gene Rep. 2020, 19, 100598. [CrossRef]

89. Alamery, S.; Tirnaz, S.; Bayer, P.; Tollenaere, R.; Chaloub, B.; Edwards, D.; Batley, J. Genome-wide identification and comparative analysis of NBS-LRR resistance genes in Brassica napus. Crop. Pasture Sci. 2017, 69, 79-93. [CrossRef]

90. Fu, Y.; Zhang, Y.; Mason, A.S.; Lin, B.; Zhang, D.; Yu, H.; Fu, D. NBS-Encoding Genes in Brassica napus Evolved Rapidly After Allopolyploidization and Co-localize With Known Disease Resistance Loci. Front. Plant Sci. 2019, 10, 26. [CrossRef] [PubMed]

91. Graham-Taylor, C.; Kamphuis, L.G.; Derbyshire, M.C. A detailed in silico analysis of secondary metabolite biosynthesis clusters in the genome of the broad host range plant pathogenic fungus Sclerotinia sclerotiorum. BMC Genom. 2020, 21, 7. [CrossRef]

92. Stotz, H.U.; Harvey, P.J.; Haddadi, P.; Mashanova, A.; Kukol, A.; Larkan, N.J.; Borhan, M.H.; Fitt, B.D.L. Genomic evidence for genes encoding leucine-rich repeat receptors linked to resistance against the eukaryotic extra- and intracellular Brassica napus pathogens Leptosphaeria maculans and Plasmodiophora brassicae. PLoS ONE 2018, 13, e0198201. [CrossRef] [PubMed]

93. Takagi, H.; Abe, A.; Yoshida, K.; Kosugi, S.; Natsume, S.; Mitsuoka, C.; Uemura, A.; Utsushi, H.; Tamiru, M.; Takuno, S.; et al. QTL-seq: Rapid mapping of quantitative trait loci in rice by whole genome resequencing of DNA from two bulked populations. Plant J. 2013, 74, 174-183. [CrossRef]

94. Liu, S.; Yeh, C.-T.; Tang, H.M.; Nettleton, D.; Schnable, P.S. Gene mapping via bulked segregant RNA-Seq (BSR-Seq). PLoS ONE 2012, 7, e36406. [CrossRef]

95. Michelmore, R.W.; Paran, I.; Kesseli, R.V. Identification of markers linked to disease-resistance genes by bulked segregant analysis: A rapid method to detect markers. Proc. Natl. Acad. Sci. USA 1991, 88. [CrossRef]

96. Zhu, H.; Zhai, W.; Li, X.; Zhu, Y. Two QTLs controlling Clubroot resistance identified from Bulked Segregant Sequencing in Pakchoi (Brassica campestris ssp. chinensis Makino). Sci. Rep. 2019, 9, 9228. [CrossRef]

97. Fu, F.; Liu, X.; Wang, R.; Zhai, C.; Peng, G.; Yu, F.; Fernando, W.G.D. Fine mapping of Brassica napus Blackleg resistance gene Rlm1 through bulked segregant RNA sequencing. Sci. Rep. 2019, 9, 14600. [CrossRef]

98. Dakouri, A.; Zhang, X.; Peng, G.; Falk, K.C.; Gossen, B.D.; Strelkov, S.E.; Yu, F. Analysis of genome-wide variants through bulked segregant RNA sequencing reveals a major gene for resistance to Plasmodiophora brassicae in Brassica oleracea. Sci. Rep. 2018, 8, 17657. [CrossRef]

99. Huang, Z.; Peng, G.; Liu, X.; Deora, A.; Falk, K.C.; Gossen, B.D.; McDonald, M.R.; Yu, F. Fine mapping of a Clubroot resistance gene in Chinese cabbage using SNP markers identified from bulked segregant RNA sequencing. Front. Plant Sci. 2017, 8, 1448. [CrossRef] [PubMed]

100. Chang, A.; Lamara, M.; Wei, Y.; Hu, H.; Parkin, I.A.P.; Gossen, B.D.; Peng, G.; Yu, F. Clubroot resistance gene Rcr6 in Brassica nigra resides in a genomic region homologous to chromosome A08 in B. rapa. BMC Plant Biol. 2019, 19, 224. [CrossRef] [PubMed]

101. Pang, W.; Fu, P.; Li, X.; Zhan, Z.; Yu, S.; Piao, Z. Identification and mapping of the Clubroot resistance gene CRd in Chinese Cabbage (Brassica rapa ssp. pekinensis). Front. Plant Sci. 2018, 9, 653. [CrossRef] [PubMed]

102. Jupe, F.; Witek, K.; Verweij, W.; Śliwka, J.; Pritchard, L.; Etherington, G.J.; Maclean, D.; Cock, P.J.; Leggett, R.M.; Bryan, G.J.; et al. Resistance gene enrichment sequencing (RenSeq) enables reannotation of the NB-LRR gene family from sequenced plant genomes and rapid mapping of resistance loci in segregating populations. Plant J. 2013, 76, 530-544. [CrossRef] 
103. Cevik, V.; Boutrot, F.; Apel, W.; Robert-Seilaniantz, A.; Furzer, O.J.; Redkar, A.; Castel, B.; Kover, P.X.; Prince, D.C.; Holub, E.B.; et al. Transgressive segregation reveals mechanisms of Arabidopsis; immunity to Brassica-infecting races of white rust (Albugo candida). Proc. Natl. Acad. Sci. USA 2019, 116, 2767. [CrossRef]

104. Van de Weyer, A.-L.; Monteiro, F.; Furzer, O.J.; Nishimura, M.T.; Cevik, V.; Witek, K.; Jones, J.D.G.; Dangl, J.L.; Weigel, D.; Bemm, F. A species-wide inventory of NLR genes and alleles in Arabidopsis thaliana. Cell 2019, 178, 1260-1272.e14. [CrossRef]

105. Domazakis, E.; Lin, X.; Aguilera-Galvez, C.; Wouters, D.; Bijsterbosch, G.; Wolters, P.J.; Vleeshouwers, V.G.A.A. Effectoromics-based identification of cell surface receptors in potato. In Plant Pattern Recognition Receptors-Methods in Molecular Biology; Shan, L., He, P., Eds.; Humana Press: New York, NY, USA, 2017; Volume 1578.

106. Rodriguez-Moreno, L.; Song, Y.; Thomma, B.P.H.J. Transfer and engineering of immune receptors to improve recognition capacities in crops. Curr. Opin. Plant Biol. 2017, 38, 42-49. [CrossRef]

107. Gu, B.; Cao, X.; Zhou, X.; Chen, Z.; Wang, Q.; Liu, W.; Chen, Q.; Zhao, H. The histological, effectoromic, and transcriptomic analyses of Solanum pinnatisectum reveal an upregulation of multiple NBS-LRR genes suppressing Phytophthora infestans infection. Int. J. Mol. Sci. 2020, 21, 3211. [CrossRef]

108. Aguilera-Galvez, C.; Champouret, N.; Rietman, H.; Lin, X.; Wouters, D.; Chu, Z.; Jones, J.D.G.; Vossen, J.H.; Visser, R.G.F.; Wolters, P.J.; et al. Two different R gene loci co-evolved with Avr2 of Phytophthora infestans and confer distinct resistance specificities in potato. Stud. Mycol. 2018, 89, 105-115. [CrossRef]

109. Wani, Z.A.; Ashraf, N. Transcriptomic studies revealing enigma of plant-pathogen interaction. In Molecular Aspects of Plant-Pathogen Interaction; Singh, A., Singh, I.K., Eds.; Springer: Singapore, 2018; pp. 219-238. [CrossRef]

110. Wang, B.; Kumar, V.; Olson, A.; Ware, D. Reviving the transcriptome studies: An insight into the emergence of single-molecule transcriptome sequencing. Front. Genet. 2019, 10, 384. [CrossRef]

111. Wang, Z.; Gerstein, M.; Snyder, M. RNA-Seq: A revolutionary tool for transcriptomics. Nat. Rev. Genet. $2009,10$. [CrossRef] [PubMed]

112. Metzker, M.L. Sequencing technologies-The next generation. Nat. Rev. Genet. 2010, 11, 31-46. [CrossRef] [PubMed]

113. Westermann, A.J.; Gorski, S.A.; Vogel, J. Dual RNA-seq of pathogen and host. Nat. Rev. Microbiol. 2012, 10, 618-630. [CrossRef] [PubMed]

114. Harper, A.L.; Trick, M.; Higgins, J.; Fraser, F.; Clissold, L.; Wells, R.; Hattori, C.; Werner, P.; Bancroft, I. Associative transcriptomics of traits in the polyploid crop species Brassica napus. Nat. Biotechnol. 2012, 30, 798-802. [CrossRef]

115. Adams, K.L.; Cronn, R.; Percifield, R.; Wendel, J.F. Genes duplicated by polyploidy show unequal contributions to the transcriptome and organ-specific reciprocal silencing. Proc. Natl. Acad. Sci. USA 2003, 100, 4649. [CrossRef]

116. Larkan, N.J.; Ma, L.; Borhan, M.H. The Brassica napus receptor-like protein RLM2 is encoded by a second allele of the LepR3/Rlm2 Blackleg resistance locus. Plant Biotechnol. J. 2015, 13, 983-992. [CrossRef]

117. Larkan, N.J.; Ma, L.; Haddadi, P.; Buchwaldt, M.; Parkin, I.A.P.; Djavaheri, M.; Borhan, M.H. The Brassica napus Wall-Associated Kinase-Like (WAKL) gene Rlm9 provides race-specific Blackleg resistance. bioRxiv 2019. [CrossRef]

118. Zhou, T.; Xu, W.; Hirani, A.H.; Liu, Z.; Tuan, P.A.; Ayele, B.T.; Daayf, F.; McVetty, P.B.E.; Duncan, R.W.; $\mathrm{Li}, \mathrm{G}$. Transcriptional insight into Brassica napus resistance genes LepR3 and Rlm2-mediated defense response against the Leptosphaeria maculans infection. Front. Plant Sci. 2019, 10, 823. [CrossRef]

119. Dmochowska-Boguta, M.; Kloc, Y.; Zielezinski, A.; Werecki, P.; Nadolska-Orczyk, A.; Karlowski, W.M.; Orczyk, W. TaWAK6 encoding wall-associated kinase is involved in wheat resistance to leaf rust similar to adult plant resistance. PLoS ONE 2020, 15, e0227713. [CrossRef]

120. Brutus, A.; Sicilia, F.; Macone, A.; Cervone, F.; De Lorenzo, G. A domain swap approach reveals a role of the plant wall-associated kinase 1 (WAK1) as a receptor of oligogalacturonides. Proc. Natl. Acad. Sci. USA 2010, 107, 9452. [CrossRef]

121. Haddadi, P.; Larkan, N.J.; Borhan, M.H. Dissecting R gene and host genetic background effect on the Brassica napus defense response to Leptosphaeria maculans. Sci. Rep. 2019, 9, 6947. [CrossRef] [PubMed] 
122. Haddadi, P.; Ma, L.; Wang, H.; Borhan, M.H. Genome-wide transcriptomic analyses provide insights into the lifestyle transition and effector repertoire of Leptosphaeria maculans during the colonization of Brassica napus seedlings. Mol. Plant Pathol. 2016, 17, 1196-1210. [CrossRef] [PubMed]

123. Becker, M.G.; Zhang, X.; Walker, P.L.; Wan, J.C.; Millar, J.L.; Khan, D.; Granger, M.J.; Cavers, J.D.; Chan, A.C.; Fernando, D.W.G.; et al. Transcriptome analysis of the Brassica napus-Leptosphaeria maculans pathosystem identifies receptor, signaling and structural genes underlying plant resistance. Plant J. 2017, 90, 573-586. [CrossRef] [PubMed]

124. Ma, L.; Djavaheri, M.; Wang, H.; Larkan, N.J.; Haddadi, P.; Beynon, E.; Gropp, G.; Borhan, M.H. Leptosphaeria maculans effector protein AvrLm1 modulates plant immunity by enhancing MAP kinase 9 phosphorylation. iScience 2018, 3, 177-191. [CrossRef]

125. Jammes, F.; Yang, X.; Xiao, S.; Kwak, J.M. Two Arabidopsis guard cell-preferential MAPK genes, MPK9 and MPK12, function in biotic stress response. Plant Signal. Behav. 2011, 6, 1875-1877. [CrossRef]

126. Lee, Y.; Kim, Y.J.; Kim, M.-H.; Kwak, J.M. MAPK cascades in guard cell sgnal transduction. Front. Plant Sci. 2016, 7, 80. [CrossRef]

127. Ueno, H.; Matsumoto, E.; Aruga, D.; Kitagawa, S.; Matsumura, H.; Hayashida, N. Molecular characterization of the CRa gene conferring clubroot resistance in Brassica rapa. Plant Mol. Biol. 2012, 80, 621-629. [CrossRef]

128. Hatakeyama, K.; Suwabe, K.; Tomita, R.N.; Kato, T.; Nunome, T.; Fukuoka, H.; Matsumoto, S. Identification and characterization of Crr1a, a gene for resistance to clubroot disease (Plasmodiophora brassicae Woronin) in Brassica rapa L. PLoS ONE 2013, 8, e54745. [CrossRef]

129. Shah, N.; Li, Q.; Xu, Q.; Liu, J.; Huang, F.; Zhan, Z.; Qin, P.; Zhou, X.; Yu, W.; Zhu, L.; et al. CRb and PbBa8.1 synergically increases resistant genes expression upon infection of Plasmodiophora brassicae in Brassica napus. Genes 2020, 11, 202. [CrossRef]

130. Meng, X.; Zhang, S. MAPK cascades in plant disease resistance signaling. Ann. Rev. Phytopathol. 2013, 51, 245-266. [CrossRef]

131. Chen, J.; Pang, W.; Chen, B.; Zhang, C.; Piao, Z. Transcriptome analysis of Brassica rapa Near-Isogenic Lines carrying Clubroot-resistant and -susceptible alleles in response to Plasmodiophora brassicae during early Infection. Front. Plant Sci. 2016, 6, 1183. [CrossRef] [PubMed]

132. Ji, R.; Wang, Y.; Wang, X.; Liu, Y.; Shen, X.; Feng, H. Proteomic analysis of the interaction between Plasmodiophora brassicae and Chinese cabbage (Brassica rapa L. ssp. Pekinensis) at the initial infection stage. Sci. Hortic. 2018, 233, 386-393. [CrossRef]

133. Ji, R.; Gao, S.; Bi, Q.; Wang, Y.; Lv, M.; Ge, W.; Feng, H. The salicylic acid signaling pathway plays an important role in the resistant process of Brassica rapa L. ssp. pekinensis to Plasmodiophora brassicae Woronin. J. Plant Growth Regul. 2020, 1-18. [CrossRef]

134. Chu, M.; Song, T.; Falk, K.C.; Zhang, X.; Liu, X.; Chang, A.; Lahlali, R.; McGregor, L.; Gossen, B.D.; $\mathrm{Yu}, \mathrm{F}$; et al. Fine mapping of Rcr1 and analyses of its effect on transcriptome patterns during infection by Plasmodiophora brassicae. BMC Genom. 2014, 15, 1-20. [CrossRef]

135. Galindo-González, L.; Manolii, V.; Hwang, S.-F.; Strelkov, S.E. Response of Brassica napus to Plasmodiophora brassicae involves salicylic acid-mediated immunity: An RNA-seq-based study. Front. Plant Sci. 2020, 11, 1025. [CrossRef]

136. Qasim, M.U.; Zhao, Q.; Shahid, M.; Samad, R.A.; Ahmar, S.; Wu, J.; Fan, C.; Zhou, Y. Identification of QTLs containing resistance genes for Sclerotinia Stem Rot in Brassica napus using comparative transcriptomic studies. Front. Plant Sci. 2020, 11, 776. [CrossRef]

137. Wu, J.; Zhao, Q.; Yang, Q.; Liu, H.; Li, Q.; Yi, X.; Cheng, Y.; Guo, L.; Fan, C.; Zhou, Y. Comparative transcriptomic analysis uncovers the complex genetic network for resistance to Sclerotinia sclerotiorum in Brassica napus. Sci. Rep. 2016, 6, 19007. [CrossRef]

138. Girard, I.J.; Tong, C.; Becker, M.G.; Mao, X.; Huang, J.; de Kievit, T.; Fernando, W.G.D.; Liu, S.; Belmonte, M.F. RNA sequencing of Brassica napus reveals cellular redox control of Sclerotinia infection. J. Exp. Bot. 2017, 68, 5079-5091. [CrossRef]

139. Wang, Z.; Ma, L.-Y.; Li, X.; Zhao, F.-Y.; Sarwar, R.; Cao, J.; Li, Y.-L.; Ding, L.-N.; Zhu, K.-M.; Yang, Y.-H.; et al. Genome-wide identification of the NPR1-like gene family in Brassica napus and functional characterization of BnaNPR1 in resistance to Sclerotinia sclerotiorum. Plant Cell Rep. 2020, 39, 709-722. [CrossRef] 
140. Zhong, X.; Zhou, Q.; Cui, N.; Cai, D.; Tang, G. BvcZR3 and BvHs1pro-1 genes pyramiding enhanced beet cyst nematode (Heterodera schachtii Schm.) resistance in oilseed rape (Brassica napus L.). Int. J. Mol. Sci. 2019, 20, 1740. [CrossRef]

141. Zhang, Y.; Huai, D.; Yang, Q.; Cheng, Y.; Ma, M.; Kliebenstein, D.J.; Zhou, Y. Overexpression of three glucosinolate biosynthesis genes in Brassica napus identifies enhanced resistance to Sclerotinia sclerotiorum and Botrytis cinerea. PLoS ONE 2015, 10, e0140491. [CrossRef]

142. Ding, Y.; Mei, J.; Chai, Y.; Yu, Y.; Shao, C.; Wu, Q.; Disi, J.O.; Li, Y.; Wan, H.; Qian, W. Simultaneous transcriptome analysis of host and pathogen highlights the interaction between Brassica oleracea and Sclerotinia sclerotiorum. Phytopathology 2018, 109, 542-550. [CrossRef]

143. Mei, J.; Ding, Y.; Li, Y.; Tong, C.; Du, H.; Yu, Y.; Wan, H.; Xiong, Q.; Yu, J.; Liu, S.; et al. Transcriptomic comparison between Brassica oleracea and rice (Oryza sativa) reveals diverse modulations on cell death in response to Sclerotinia sclerotiorum. Sci. Rep. 2016, 6, 33706. [CrossRef]

144. Zheng, H.; Zhang, Y.; Li, J.; He, L.; Wang, F.; Bi, Y.; Gao, J. Comparative transcriptome analysis between a resistant and a susceptible Chinese cabbage in response to Hyaloperonospora brassicae. Plant Signal. Behav. 2020, 15, 1777373. [CrossRef]

145. Xiao, D.; Liu, S.-T.; Wei, Y.-P.; Zhou, D.-Y.; Hou, X.-L.; Li, Y.; Hu, C.-M. cDNA-AFLP analysis reveals differential gene expression in incompatible interaction between infected non-heading Chinese cabbage and Hyaloperonospora parasitica. Hortic. Res. 2016, 3, 16034. [CrossRef]

146. Xing, M.; Lv, H.; Ma, J.; Xu, D.; Li, H.; Yang, L.; Kang, J.; Wang, X.; Fang, Z. Transcriptome profiling of resistance to Fusarium oxysporum f. sp. conglutinans in cabbage (Brassica oleracea) roots. PLoS ONE 2016, 11, e0148048. [CrossRef]

147. Tortosa, M.; Cartea, M.E.; Velasco, P.; Soengas, P.; Rodriguez, V.M. Calcium-signaling proteins mediate the plant transcriptomic response during a well-established Xanthomonas campestris pv. campestris infection. Hortic. Res. 2019, 6, 103. [CrossRef]

148. Liu, M.; Wu, F.; Wang, S.; Lu, Y.; Chen, X.; Wang, Y.; Gu, A.; Zhao, J.; Shen, S. Comparative transcriptome analysis reveals defense responses against soft rot in Chinese cabbage. Hortic. Res. 2019, 6, 68. [CrossRef]

149. Mehta, A.; Brasileiro, A.C.M.; Souza, D.S.L.; Romano, E.; Campos, M.A.; Grossi-de-Sá, M.F.; Silva, M.S.; Franco, O.L.; Fragoso, R.R.; Bevitori, R.; et al. Plant-pathogen interactions: What is proteomics telling us? FEBS J. 2008, 275, 3731-3746. [CrossRef]

150. Marra, R.; Li, H.; Barbetti, M.J.; Sivasithamparam, K.; Vinale, F.; Cavallo, P.; Lorito, M. Proteomic analysis of the interaction between Brassica napus cv. Surpass 400 and virulent or avirulent isolates of Leptosphaeria maculans. J. Plant Pathol. 2010, 92, 89-101.

151. Sharma, N.; Hotte, N.; Rahman, M.H.; Mohammadi, M.; Deyholos, M.K.; Kav, N.N.V. Towards identifying Brassica proteins involved in mediating resistance to Leptosphaeria maculans: A proteomics-based approach. Proteomics 2008, 8, 3516-3535. [CrossRef] [PubMed]

152. Subramanian, B.; Bansal, V.K.; Kav, N.N. Proteome-level investigation of Brassica carinata-derived resistance to Leptosphaeria maculans. J. Agric. Food Chem. 2005, 53, 313-324. [CrossRef] [PubMed]

153. Song, T.; Chu, M.; Lahlali, R.; Yu, F.; Peng, G. Shotgun label-free proteomic analysis of Clubroot (Plasmodiophora brassicae) resistance conferred by the gene Rcr1 in Brassica rapa. Front. Plant Sci. 2016, 7, 1013. [CrossRef] [PubMed]

154. Moon, J.Y.; Kim, S.T.; Choi, G.J.; Kwon, S.-Y.; Cho, H.S.; Kim, H.-S.; Moon, J.S.; Park, J.M. Comparative proteomic analysis of host responses to Plasmodiophora brassicae infection in susceptible and resistant Brassica oleracea. Plant Biotech. Rep. 2020, 14, 263-274. [CrossRef]

155. Lan, M.; Li, G.; Hu, J.; Yang, H.; Zhang, L.; Xu, X.; Liu, J.; He, J.; Sun, R. iTRAQ-based quantitative analysis reveals proteomic changes in Chinese cabbage (Brassica rapa L.) in response to Plasmodiophora brassicae infection. Sci. Rep. 2019, 9, 12058. [CrossRef]

156. Sun, C.; Wang, L.; Hu, D.; Riquicho, A.R.M.; Liu, T.; Hou, X.; Li, Y. Proteomic analysis of non-heading Chinese cabbage infected with Hyaloperonospora parasitica. J. Proteom. 2014, 98, 15-30. [CrossRef]

157. Rustagi, A.; Singh, G.; Agrawal, S.; Gupta, P.K. Proteomic studies revealing enigma of plant-pathogen interaction. In Molecular Aspects of Plant-Pathogen Interaction; Singh, A., Singh, I.K., Eds.; Springer: Singapore, 2018; pp. 239-264. [CrossRef] 
158. Kaur, P.; Jost, R.; Sivasithamparam, K.; Barbetti, M.J. Proteome analysis of the Albugo candida-Brassica juncea pathosystem reveals that the timing of the expression of defence-related genes is a crucial determinant of pathogenesis. J. Exp. Bot. 2011, 62, 1285-1298. [CrossRef]

159. Shrivastava, N.; Jiang, L.; Li, P.; Sharma, A.K.; Luo, X.; Wu, S.; Pandey, R.; Gao, Q.; Lou, B. Proteomic approach to understand the molecular physiology of symbiotic interaction between Piriformospora indica and Brassica napus. Sci. Rep. 2018, 8, 5773. [CrossRef]

160. Dutreux, F.; Da Silva, C.; d'Agata, L.; Couloux, A.; Gay, E.J.; Istace, B.; Lapalu, N.; Lemainque, A.; Linglin, J.; Noel, B.; et al. De novo assembly and annotation of three Leptosphaeria genomes using Oxford Nanopore MinION sequencing. Sci. Data 2018, 5, 180235. [CrossRef]

161. Derbyshire, M.; Denton-Giles, M.; Hegedus, D.; Seifbarghy, S.; Rollins, J.; van Kan, J.; Seidl, M.F.; Faino, L.; Mbengue, M.; Navaud, O.; et al. The complete genome sequence of the phytopathogenic fungus Sclerotinia sclerotiorum reveals insights into the genome architecture of broad host range pathogens. Genome Biol. Evol. 2017, 9, 593-618. [CrossRef]

162. Rajarammohan, S.; Pental, D.; Kaur, J. Near-complete genome assembly of Alternaria brassicae-A necrotrophic pathogen of Brassica crops. Mol. Plant Microbe Interact. 2019, 32, 928-930. [CrossRef]

163. Rajarammohan, S.; Paritosh, K.; Pental, D.; Kaur, J. Comparative genomics of Alternaria species provides insights into the pathogenic lifestyle of Alternaria brassicae-A pathogen of the Brassicaceae family. BMC Genom. 2019, 20, 1036. [CrossRef]

164. Daval, S.; Belcour, A.; Gazengel, K.; Legrand, L.; Gouzy, J.; Cottret, L.; Lebreton, L.; Aigu, Y.; Mougel, C.; Manzanares-Dauleux, M.J. Computational analysis of the Plasmodiophora brassicae genome: Mitochondrial sequence description and metabolic pathway database design. Genomics 2019, 111, 1629-1640. [CrossRef] [PubMed]

165. Links, M.G.; Holub, E.; Jiang, R.H.Y.; Sharpe, A.G.; Hegedus, D.; Beynon, E.; Sillito, D.; Clarke, W.E.; Uzuhashi, S.; Borhan, M.H. De novo sequence assembly of Albugo candida reveals a small genome relative to other biotrophic oomycetes. BMC Genom. 2011, 12, 503. [CrossRef] [PubMed]

166. Tsushima, A.; Gan, P.; Kumakura, N.; Narusaka, M.; Takano, Y.; Narusaka, Y.; Shirasu, K. Genomic Plasticity Mediated by Transposable Elements in the Plant Pathogenic Fungus Colletotrichum higginsianum. Genome Biol. Evol. 2019, 11, 1487-1500. [CrossRef] [PubMed]

167. Shi-Kunne, X.; Faino, L.; van den Berg, G.C.M.; Thomma, B.P.H.J.; Seidl, M.F. Evolution within the fungal genus Verticillium is characterized by chromosomal rearrangement and gene loss. Environ. Microbiol. 2018, 20, 1362-1373. [CrossRef] [PubMed]

168. Mousavi-Derazmahalleh, M.; Chang, S.; Thomas, G.; Derbyshire, M.; Bayer, P.E.; Edwards, D.; Nelson, M.N.; Erskine, W.; Lopez-Ruiz, F.J.; Clements, J.; et al. Prediction of pathogenicity genes involved in adaptation to a lupin host in the fungal pathogens Botrytis cinerea and Sclerotinia sclerotiorum via comparative genomics. BMC Genom. 2019, 20, 385. [CrossRef]

169. Bertazzoni, S.; Williams, A.H.; Jones, D.A.; Syme, R.A.; Tan, K.-C.; Hane, J.K. Accessories Make the Outfit: Accessory Chromosomes and Other Dispensable DNA Regions in Plant-Pathogenic Fungi. Mol. Plant Microbe Interact. 2018, 31, 779-788. [CrossRef]

170. Covo, S. Genomic Instability in Fungal Plant Pathogens. Genes 2020, 11, 421. [CrossRef]

171. Peng, Z.; Oliveira-Garcia, E.; Lin, G.; Hu, Y.; Dalby, M.; Migeon, P.; Tang, H.; Farman, M.; Cook, D.; White, F.F.; et al. Effector gene reshuffling involves dispensable mini-chromosomes in the wheat blast fungus. PLoS Genet. 2019, 15, e1008272. [CrossRef]

172. Möller, M.; Stukenbrock, E.H. Evolution and genome architecture in fungal plant pathogens. Nat. Rev. Microbiol. 2017, 15, 756. [CrossRef] [PubMed]

173. Feurtey, A.; Stevens, D.M.; Stephan, W.; Stukenbrock, E.H. Interspecific Gene Exchange Introduces High Genetic Variability in Crop Pathogen. Genome Biol. Evol. 2019, 11, 3095-3105. [CrossRef] [PubMed]

174. Stjelja, S.; Fogelqvist, J.; Tellgren-Roth, C.; Dixelius, C. The architecture of the Plasmodiophora brassicae nuclear and mitochondrial genomes. Sci. Rep. 2019, 9, 15753. [CrossRef] [PubMed]

175. Chittem, K.; Yajima, W.R.; Goswami, R.S.; Del Río Mendoza, L.E. Transcriptome analysis of the plant pathogen Sclerotinia sclerotiorum interaction with resistant and susceptible canola (Brassica napus) lines. PLoS ONE 2020, 15, e0229844. [CrossRef]

176. Sonah, H.; Deshmukh, R.K.; Bélanger, R.R. Computational prediction of effector proteins in fungi: Opportunities and challenges. Front. Plant Sci. 2016, 7. [CrossRef] 
177. Pérez-López, E.; Waldner, M.; Hossain, M.; Kusalik, A.J.; Wei, Y.; Bonham-Smith, P.C.; Todd, C.D. Identification of Plasmodiophora brassicae effectors-A challenging goal. Virulence 2018, 9, 1344-1353. [CrossRef]

178. Chen, W.; Li, Y.; Yan, R.; Xu, L.; Ren, L.; Liu, F.; Zeng, L.; Yang, H.; Chi, P.; Wang, X.; et al. Identification and characterization of Plasmodiophora brassicae primary infection effector candidates that suppress or induce cell death in host and nonhost plants. Phytopathology 2019, 109, 1689-1697. [CrossRef]

179. Büttner, D.; Bonas, U. Regulation and secretion of Xanthomonas virulence factors. FEMS Microbiol. Rev. 2010, 34, 107-133. [CrossRef]

180. Charkowski, A.; Blanco, C.; Condemine, G.; Expert, D.; Franza, T.; Hayes, C.; Hugouvieux-Cotte-Pattat, N.; Solanilla, E.L.; Low, D.; Moleleki, L.; et al. The role of secretion systems and small molecules in Soft-Rot Enterobacteriaceae pathogenicity. Ann. Rev. Phytopathol. 2011, 50, 425-449. [CrossRef]

181. Lee, D.H.; Lim, J.-A.; Lee, J.; Roh, E.; Jung, K.; Choi, M.; Oh, C.; Ryu, S.; Yun, J.; Heu, S. Characterization of genes required for the pathogenicity of Pectobacterium carotovorum subsp. carotovorum Pcc21 in Chinese cabbage. Microbiology 2013, 159, 1487-1496. [CrossRef]

182. Seifbarghi, S.; Borhan, M.H.; Wei, Y.; Coutu, C.; Robinson, S.J.; Hegedus, D.D. Changes in the Sclerotinia sclerotiorum transcriptome during infection of Brassica napus. BMC Genom. 2017, 18, 266. [CrossRef] [PubMed]

183. Vincent, D.; Plummer, K.M.; Solomon, P.S.; Lebrun, M.-H.; Job, D.; Rafiqi, M. Editorial: How can secretomics help unravel the secrets of plant-microbe interactions? Front. Plant Sci. 2016, 7, 1777. [CrossRef] [PubMed]

184. Kim, K.-T.; Jeon, J.; Choi, J.; Cheong, K.; Song, H.; Choi, G.; Kang, S.; Lee, Y.-H. Kingdom-wide analysis of fungal small secreted proteins (SSPs) reveals their potential role in host association. Front. Plant Sci. 2016, 7, 186. [CrossRef]

185. Van de Wouw, A.P.; Idnurm, A. Biotechnological potential of engineering pathogen effector proteins for use in plant disease management. Biotechnol. Adv. 2019, 37, 107387. [CrossRef]

186. Depotter, J.R.L.; Doehlemann, G. Target the core: Durable plant resistance against filamentous plant pathogens through effector recognition. Pest Manag. Sci. 2020, 76, 426-431. [CrossRef]

187. Sperschneider, J.; Dodds, P.N.; Gardiner, D.M.; Singh, K.B.; Taylor, J.M. Improved prediction of fungal effector proteins from secretomes with EffectorP 2.0. Mol. Plant Pathol. 2018, 19, 2094-2110. [CrossRef]

188. Franceschetti, M.; Maqbool, A.; Jiménez-Dalmaroni, M.J.; Pennington, H.G.; Kamoun, S.; Banfield, M.J. Effectors of filamentous plant pathogens: Commonalities amid diversity. Microbiol. Mol. Biol. Rev. 2017, 81. [CrossRef]

189. Almagro Armenteros, J.J.; Tsirigos, K.D.; Sønderby, C.K.; Petersen, T.N.; Winther, O.; Brunak, S.; von Heijne, G.; Nielsen, H. SignalP 5.0 improves signal peptide predictions using deep neural networks. Nat. Biotechnol. 2019, 37, 420-423. [CrossRef]

190. Sperschneider, J.; Dodds, P.N.; Singh, K.B.; Taylor, J.M. ApoplastP: Prediction of effectors and plant proteins in the apoplast using machine learning. New Phytol. 2017, 217, 1764-1778. [CrossRef]

191. Carreón-Anguiano, K.G.; Islas-Flores, I.; Vega-Arreguín, J.; Sáenz-Carbonell, L.; Canto-Canché, B. EffHunter: A tool for prediction of effector protein candidates in fungal proteomic databases. Biomolecules 2020, 10, 712. [CrossRef]

192. Collemare, J.; O'Connell, R.; Lebrun, M.-H. Nonproteinaceous effectors: The terra incognita of plant-fungal interactions. New Phytol. 2019, 223, 590-596. [CrossRef] [PubMed]

193. Ruano, G.; Scheuring, D. Plant cells under attack: Unconventional endomembrane trafficking during plant defense. Plants 2020, 9, 389. [CrossRef] [PubMed]

194. Tanveer, T.; Shaheen, K.; Parveen, S.; Kazi, A.G.; Ahmad, P. Plant secretomics. Plant Signal. Behav. 2014, 9, e29426. [CrossRef] [PubMed]

195. Vincent, D.; Rafiqi, M.; Job, D. The multiple facets of plant-fungal interactions revealed through plant and fungal secretomics. Front. Plant Sci. 2020, 10, 1626. [CrossRef]

196. Gupta, R.; Lee, S.E.; Agrawal, G.K.; Rakwal, R.; Park, S.; Wang, Y.; Kim, S.T. Understanding the plant-pathogen interactions in the context of proteomics-generated apoplastic proteins inventory. Front. Plant Sci. 2015, 6, 352. [CrossRef]

197. Deboever, E.; Deleu, M.; Mongrand, S.; Lins, L.; Fauconnier, M.-L. Plant-Pathogen Interactions: Underestimated Roles of Phyto-oxylipins. Trends Plant Sci. 2020, 25, 22-34. [CrossRef] 
198. Genva, M.; Obounou Akong, F.; Andersson, M.X.; Deleu, M.; Lins, L.; Fauconnier, M.-L. New insights into the biosynthesis of esterified oxylipins and their involvement in plant defense and developmental mechanisms. Phytochem. Rev. 2019, 18, 343-358. [CrossRef]

199. Granér, G.; Hamberg, M.; Meijer, J. Screening of oxylipins for control of oilseed rape (Brassica napus) fungal pathogens. Phytochemistry 2003, 63, 89-95. [CrossRef]

200. Fischer, G.J.; Keller, N.P. Production of cross-kingdom oxylipins by pathogenic fungi: An update on their role in development and pathogenicity. J. Microbiology 2016, 54, 254-264. [CrossRef]

201. Patkar, R.N.; Naqvi, N.I. Fungal manipulation of hormone-regulated plant defense. PLoS Pathog. 2017, 13, e1006334. [CrossRef]

202. Thatcher, L.F.; Manners, J.M.; Kazan, K. Fusarium oxysporum hijacks COI1-mediated jasmonate signaling to promote disease development in Arabidopsis. Plant J. 2009, 58, 927-939. [CrossRef] [PubMed]

203. Spallek, T.; Gan, P.; Kadota, Y.; Shirasu, K. Same tune, different song-Cytokinins as virulence factors in plant-pathogen interactions? Curr. Opin. Plant Biol. 2018, 44, 82-87. [CrossRef] [PubMed]

204. Darma, R.; Lutz, A.; Elliott, C.E.; Idnurm, A. Identification of a gene cluster for the synthesis of the plant hormone abscisic acid in the plant pathogen Leptosphaeria maculans. Fungal Genet. Biol. 2019, 130, 62-71. [CrossRef] [PubMed]

205. Ludwig-Müller, J.; Jülke, S.; Geiß, K.; Richter, F.; Mithöfer, A.; Šola, I.; Rusak, G.; Keenan, S.; Bulman, S. A novel methyltransferase from the intracellular pathogen Plasmodiophora brassicae methylates salicylic acid. Mol. Plant Pathol. 2015, 16. [CrossRef] [PubMed]

206. Ciaghi, S.; Schwelm, A.; Neuhauser, S. Transcriptomic response in symptomless roots of clubroot infected kohlrabi (Brassica oleracea var. gongylodes) mirrors resistant plants. BMC Plant Biol. 2019, 19, 288. [CrossRef]

207. Djavaheri, M.; Ma, L.; Klessig, D.F.; Mithöfer, A.; Gropp, G.; Borhan, H. Mimicking the host regulation of salicylic acid: A virulence strategy by the Clubroot pathogen Plasmodiophora brassicae. Mol. Plant Microbe Interact. 2018, 32, 296-305. [CrossRef]

208. Pathak, R.K.; Baunthiyal, M.; Shukla, R.; Pandey, D.; Taj, G.; Kumar, A. In silico identification of mimicking molecules as defense inducers triggering jasmonic acid mediated immunity against Alternaria Blight disease in Brassica species. Front. Plant Sci. 2017, 8, 609. [CrossRef]

209. Romero, F.M.; Rossi, F.R.; Gárriz, A.; Carrasco, P.; Ruíz, O.A. A bacterial endophyte from apoplast fluids protects canola plants from different phytopathogens via antibiosis and induction of host resistance. Phytopathology 2018, 109, 375-383. [CrossRef]

210. Tian, X.; Wang, D.; Mao, Z.; Pan, L.; Liao, J.; Cai, Z. Infection of Plasmodiophora brassicae changes the fungal endophyte community of tumourous stem mustard roots as revealed by high-throughput sequencing and culture-dependent methods. PLoS ONE 2019, 14, e0214975. [CrossRef]

211. Ahmed, H.; Howton, T.C.; Sun, Y.; Weinberger, N.; Belkhadir, Y.; Mukhtar, M.S. Network biology discovers pathogen contact points in host protein-protein interactomes. Nat. Commun. 2018, 9, 2312. [CrossRef]

212. Urban, M.; Cuzick, A.; Rutherford, K.; Irvine, A.; Pedro, H.; Pant, R.; Sadanadan, V.; Khamari, L.; Billal, S.; Mohanty, S.; et al. PHI-base: A new interface and further additions for the multi-species pathogen-host interactions database. Nucleic Acids Res. 2016, 45, D604-D610. [CrossRef] [PubMed]

213. Janowska-Sejda, E.I.; Lysenko, A.; Urban, M.; Rawlings, C.; Tsoka, S.; Hammond-Kosack, K.E. PHI-Nets: A network resource for Ascomycete fungal pathogens to annotate and identify putative virulence interacting proteins and siRNA targets. Front. Microbiol. 2019, 10, 2721. [CrossRef] [PubMed]

214. Castro-Moretti, F.R.; Gentzel, I.N.; Mackey, D.; Alonso, A.P. Metabolomics as an emerging tool for the study of plant-pathogen interactions. Metabolites 2020, 10, 52. [CrossRef]

215. Tortosa, M.; Cartea, M.E.; Rodríguez, V.M.; Velasco, P. Unraveling the metabolic response of Brassica oleracea exposed to Xanthomonas campestris pv. campestris. J. Sci. Food Agric. 2018, 98, 3675-3683. [CrossRef] [PubMed]

216. Pathak, R.K.; Baunthiyal, M.; Pandey, N.; Pandey, D.; Kumar, A. Modeling of the jasmonate signaling pathway in Arabidopsis thaliana with respect to pathophysiology of Alternaria blight in Brassica. Sci. Rep. 2017, 7, 16790. [CrossRef]

217. Botero, D.; Alvarado, C.; Bernal, A.; Danies, G.; Restrepo, S. Network analyses in plant pathogens. Front. Microbiol. 2018, 9, 35. [CrossRef] [PubMed]

218. Peyraud, R.; Mbengue, M.; Barbacci, A.; Raffaele, S. Intercellular cooperation in a fungal plant pathogen facilitates host colonization. Proc. Natl. Acad. Sci. USA 2019, 116, 3193. [CrossRef] [PubMed] 
219. Wagner, G.; Laperche, A.; Lariagon, C.; Marnet, N.; Renault, D.; Guitton, Y.; Bouchereau, A.; Delourme, R.; Manzanares-Dauleux, M.J.; Gravot, A. Resolution of quantitative resistance to clubroot into QTL-specific metabolic modules. J. Exp. Bot. 2019, 70, 5375-5390. [CrossRef]

220. Singh, A. Glucosinolates and Plant Defense. In Glucosinolates; Mérillon, J.-M., Ramawat, K.G., Eds.; Springer International Publishing: Cham, Switzerland, 2017; pp. 237-246. [CrossRef]

221. Ranjan, A.; Westrick, N.M.; Jain, S.; Piotrowski, J.S.; Ranjan, M.; Kessens, R.; Stiegman, L.; Grau, C.R.; Smith, D.L.; Kabbage, M. Integrated soybean transcriptomics, metabolomics, and chemical genomics reveal the importance of the phenylpropanoid pathway and antifungal activity in resistance to the broad host range pathogen Sclerotinia sclerotiorum. bioRxiv 2018. [CrossRef]

222. Fikere, M.; Barbulescu, D.M.; Malmberg, M.M.; Shi, F.; Koh, J.C.O.; Slater, A.T.; MacLeod, I.M.; Bowman, P.J.; Salisbury, P.A.; Spangenberg, G.C.; et al. Genomic prediction using prior Quantitative Trait Loci information reveals a large reservoir of underutilised Blackleg resistance in diverse canola (Brassica napus L.) lines. Plant Genome 2018, 11, 170100. [CrossRef]

223. Poland, J.; Rutkoski, J. Advances and challenges in genomic selection for disease resistance. Ann. Rev. Phytopathol. 2016, 54, 79-98. [CrossRef] [PubMed]

224. Zhang, R.; Zheng, F.; Wei, S.; Zhang, S.; Li, G.; Cao, P.; Zhao, S. Evolution of disease defense genes and their regulators in plants. Int. J. Mol. Sci. 2019, 20, 335. [CrossRef]

225. Tirnaz, S.; Batley, J. DNA Methylation: Toward crop disease resistance improvement. Trends Plant Sci. 2019, 24, 1137-1150. [CrossRef] [PubMed]

226. Alonso, C.; Ramos-Cruz, D.; Becker, C. The role of plant epigenetics in biotic interactions. New Phytol. 2019, 221, 731-737. [CrossRef] [PubMed]

227. Liégard, B.; Baillet, V.; Etcheverry, M.; Joseph, E.; Lariagon, C.; Lemoine, J.; Evrard, A.; Colot, V.; Gravot, A.; Manzanares-Dauleux, M.J.; et al. Quantitative resistance to Clubroot infection mediated by transgenerational epigenetic variation in Arabidopsis. New Phytol. 2019, 222, 468-479. [CrossRef]

228. Tirnaz, S.; Merce, C.; Bayer, P.E.; Severn-Ellis, A.A.; Edwards, D.; Batley, J. Effect of Leptosphaeria maculans infection on promoter DNA methylation of defence genes in Brassica napus. Agronomy 2020, 10, 1072. [CrossRef]

229. Spring, O.; Gomez-Zeledon, J.; Hadziabdic, D.; Trigiano, R.N.; Thines, M.; Lebeda, A. Biological characteristics and assessment of virulence diversity in pathosystems of economically important biotrophic oomycetes. Crit. Rev. Plant Sci. 2018, 37, 439-495. [CrossRef]

230. Sun, Q.; Lin, L.; Liu, D.; Wu, D.; Fang, Y.; Wu, J.; Wang, Y. CRISPR/Cas9-mediated multiplex genome editing of the BnWRKY11 and BnWRKY70 Genes in Brassica napus L. Int. J. Mol. Sci. 2018, 19, 2716. [CrossRef]

231. Jeong, S.Y.; Ahn, H.; Ryu, J.; Oh, Y.; Sivanandhan, G.; Won, K.-H.; Park, Y.D.; Kim, J.-S.; Kim, H.; Lim, Y.P.; et al. Generation of early-flowering Chinese cabbage (Brassica rapa spp. pekinensis) through CRISPR/Cas9-mediated genome editing. Plant Biotechnol. Rep. 2019, 13, 491-499. [CrossRef]

232. Liu, F.; Selin, C.; Zou, Z.; Dilantha Fernando, W.G. LmCBP1, a secreted chitin-binding protein, is required for the pathogenicity of Leptosphaeria maculans on Brassica napus. Fungal Genet. Biol. 2020, 136, 103320. [CrossRef]

233. Li, Q.; Yan, J. Sustainable agriculture in the era of omics: Knowledge-driven crop breeding. Genome Biol. 2020, 21, 154. [CrossRef] [PubMed]

(C) 2020 by the authors. Licensee MDPI, Basel, Switzerland. This article is an open access article distributed under the terms and conditions of the Creative Commons Attribution (CC BY) license (http://creativecommons.org/licenses/by/4.0/). 